\title{
Review \\ Glycan-Lectin Interactions in Cancer and Viral Infections and How to Disrupt Them
}

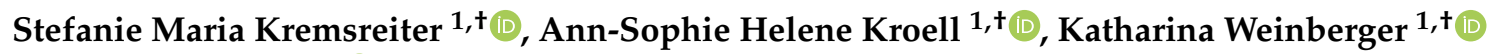 \\ and Heike Boehm $2, *$ (D) \\ 1 Institute for Pharmacy and Molecular Biotechnology (IPMB), Ruprecht Karls University Heidelberg, \\ Im Neuenheimer Feld 364, 69120 Heidelberg, Germany; \\ Stefanie.Kremsreiter@stud.uni-heidelberg.de (S.M.K.); ann-sophie@kroell.de (A.-S.H.K.); \\ weinberger@stud.uni-heidelberg.de (K.W.) \\ 2 Max-Planck-Institute for Medical Research, Jahnstr. 29, 69120 Heidelberg, Germany \\ * Correspondence: heike.boehm@mpimf-heidelberg.mpg.de \\ + These authors contributed equally to this work.
}

Citation: Kremsreiter, S.M.;

Kroell, A.-S.H.; Weinberger, K.;

Boehm, H. Glycan-Lectin Interactions in Cancer and Viral Infections and How to Disrupt Them. Int. J. Mol. Sci. 2021, 22, 10577. https://doi.org/ $10.3390 /$ ijms221910577

Academic Editor: Aamir Ahmad

Received: 10 September 2021

Accepted: 26 September 2021

Published: 30 September 2021

Publisher's Note: MDPI stays neutral with regard to jurisdictional claims in published maps and institutional affiliations.

Copyright: (c) 2021 by the authors. Licensee MDPI, Basel, Switzerland. This article is an open access article distributed under the terms and conditions of the Creative Commons Attribution (CC BY) license (https:// creativecommons.org/licenses/by/ $4.0 /)$.

\begin{abstract}
Glycan-lectin interactions play an essential role in different cellular processes. One of their main functions is involvement in the immune response to pathogens or inflammation. However, cancer cells and viruses have adapted to avail themselves of these interactions. By displaying specific glycosylation structures, they are able to bind to lectins, thus promoting pathogenesis. While glycan-lectin interactions promote tumor progression, metastasis, and/or chemoresistance in cancer, in viral infections they are important for viral entry, release, and/or immune escape. For several years now, a growing number of investigations have been devoted to clarifying the role of glycan-lectin interactions in cancer and viral infections. Various overviews have already summarized and highlighted their findings. In this review, we consider the interactions of the lectins MGL, DC-SIGN, selectins, and galectins in both cancer and viral infections together. A possible transfer of ways to target and disrupt them might lead to new therapeutic approaches in different pathological backgrounds.
\end{abstract}

Keywords: cancer; DC-SIGN; galectins; glycosylation; lectins; MGL; selectins; virus

\section{Introduction}

Glycosylation is a multistep process involving the covalent addition of saccharides to proteins or lipids at the endoplasmic reticulum and Golgi. It is one of the most common and diverse forms of the post-translational modification of proteins [1,2]. The main types include N-linked glycosylation (glycans are attached to nitrogen of asparagine) and O-linked glycosylation (glycans are attached to the hydroxyl group of serine or threonine). Moreover, the formation of oligo- and polysaccharides is defined by the monomer sequence as well as the linkage (which can be $\alpha$ or $\beta$ ), whereas the position of the linkage is highly variable $[3,4]$. Glycosylation has a major impact on structural and modulatory functions as well as cellular interactions [2].

For cell-cell or cell-pathogen interactions, glycans bind to glycan-binding proteins named lectins. Lectins are a large protein class which display a characteristic carbohydrate recognition domain (CRD) in order to bind specific glycosylation structures [2] Glycan-lectin interactions mediate many different biological processes, including cell-cell recognition, developmental processes, and protection against pathogens [1]. Even small changes in carbohydrate moieties may strongly affect interaction and consequent functionality [5]. In this review, we will focus on the interactions of glycans with four different lectins, namely galectins and three different C-type lectin receptors (CLRs) including the macrophage galactose binding lectin (MGL), the dendritic cell-specific intracellular adhesion molecule 3-grabbing nonintegrin (DC-SIGN), and selectins. We selected these four 
lectins because it has been shown that all four receptors play a key role in cancer [6,7] and in viral infection $[8,9]$ by interacting with disease-specific glycosylation patterns.

Aberrant glycosylation is a characteristic feature of cancer cells, as it is involved in many cancer-related pathways [10,11]. Incomplete synthesis of glycan structures and the formation of new structures promote a tumor-specific glyco-code [12]. This glyco-code includes different highly branched $\mathrm{N}$-glycans and truncated O-glycans as well as various terminal fucosylated or sialylated glycans or glycosphingolipids $[10,12,13]$ (Figure 1). Increased $\alpha 2,6$-sialylation is a critical aberration observed in cancer development that contributes to increasing the metastatic growth potential of tumor cells. Due to the altered ratio between $\alpha 2,3-$ and $\alpha 2,6$-linked sialic acids, several of those glycans were found to be relevant for diagnosis [14]. By binding to lectins, the tumor-specific glycans influence key biological processes including, for example, cell adhesion, signaling, and proliferation. These processes can be connected to several essential cancer hallmarks like activating invasion and metastasis, proliferative signaling, and/or avoiding immune destruction $[7,10,12]$.

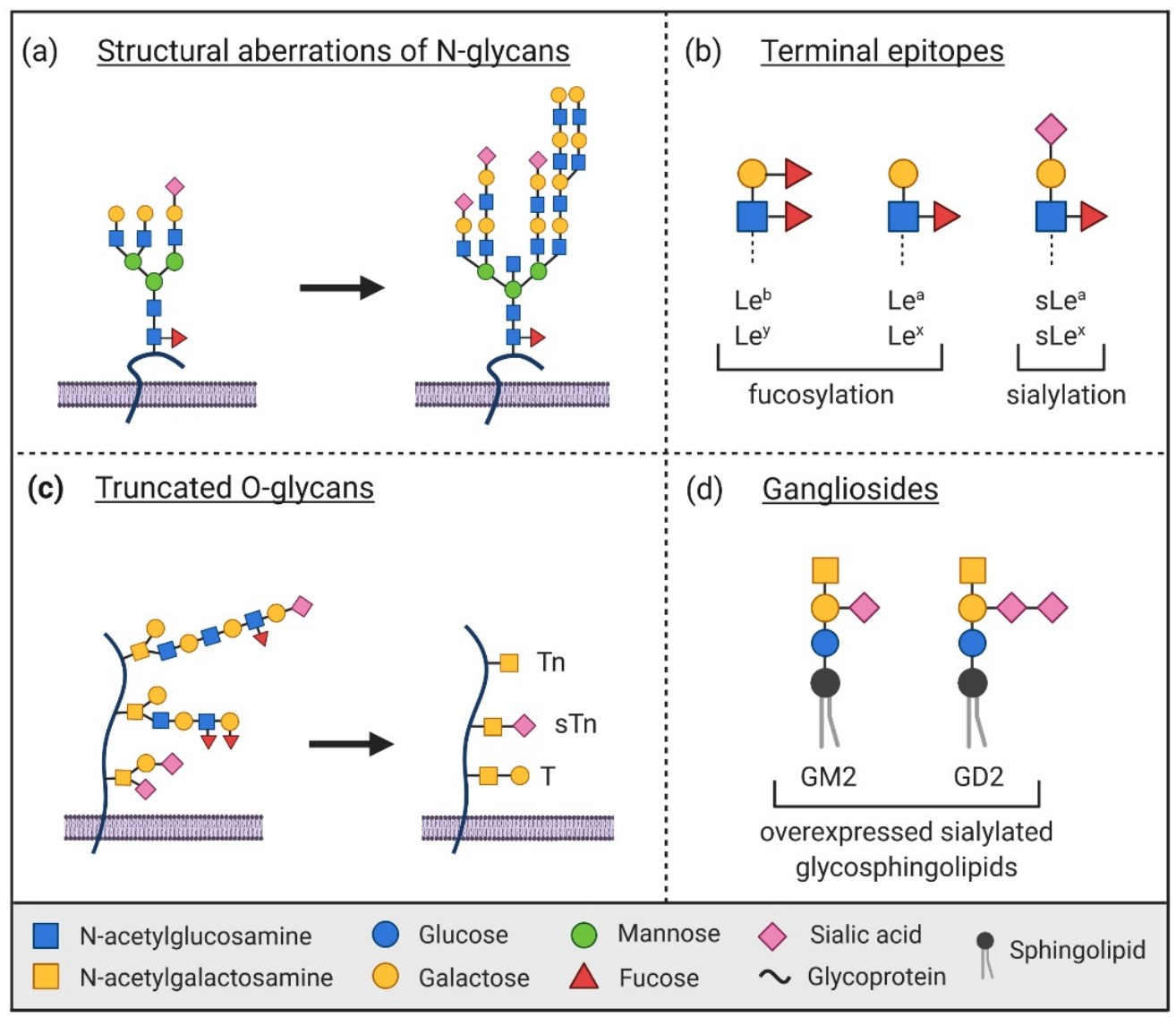

Figure 1. Common aberrations of glycan structures in cancer. (a) Altered and increased branching of N-glycans. (b) Capping of glycan structures with terminal epitopes such as the fucosylated Lewis (Le) antigen or sialylated structures like the sialyl Lewis (sLe) antigen. (c) Expression of truncated O-glycans like the monosaccharide GalNAc (Tn antigen), the sialylated Tn antigen (sTn), or the Thomsen Friedenreich antigen (T antigen). (d) Overexpression of gangliosides, a family of sialylated glycosphingolipids - for example, monosialoganglioside GM2 and disialoganglioside GD2. The figure was created with BioRender.com and is adapted from Mereiter et al., 2019 [10].

In viruses, especially enveloped viruses, glycans play also an important role by, for example, enhancing viral infectivity [15]. Since viruses are deficient in proteins such as glycosyltransferases, they exploit the cellular glycosylation machinery [16]. However, instead of undergoing the conventional process of host cell glycoproteins (GPs), viral proteins might break out of the machinery early or translocate, resulting in the formation 
of virus-specific glycans [17]. By interacting with lectins, these viral GPs can promote virulence, for example, by enabling viral attachment and host cell uptake, viral release, or immune evasion $[8,17]$.

This review covering a range of four different lectins (MGL, DC-SIGN, selectins, and galectins) provides a basic overview of current knowledge for those who are new to the glycan research field or interested in looking at glycan-lectin interactions in cancer and viral infections. Some promising therapeutic approaches are based on disrupting these interactions. For each receptor, we first present the physiological role of the receptor by addressing possible classifications, their structure, ligands, expression patterns, and their function. It is then shown how the expression of the receptor or glycan is altered in cancer. We present the tumor-promoting effects of these interactions as well as preclinically or clinically investigated strategies targeting these interactions. Similarly, we describe the role of lectins interacting with glycan patterns or GPs of well-known viruses including human immunodeficiency virus (HIV), Ebola virus (EBOV), influenza virus, and the severe acute respiratory syndrome coronavirus 2 (SARS-CoV-2). We show their role in promoting infection and discuss potential therapeutic strategies. By comparing glycanlectin interactions in cancer and viral infections, we hope to find commonalities with regard to therapeutic approaches or potential clinical methods. Such commonalities could be the basis for further investigations with the goal of translating promising therapeutic approaches in either cancer or viral infections to the other disease.

\section{Macrophage Galactose-Binding Lectin}

MGL belongs to a subgroup of type II CLRs, the galactose-type lectins [18]. CLRs have the property to bind carbohydrates in a calcium-dependent manner [19] and are divided into 14 different types based on their domain structures [20,21]. MGL consists of a single C-type, lectin-like domain (CTLD), an extracellular stalk region, a transmembrane region, and, finally, a cytoplasmic tail containing a tyrosine-based signaling motif which regulates endocytosis activity. The CRD is located inside the CTLD [22] (Figure 2a). This galactosetype lectin binds specifically to galactose-terminated glycans, in particular, terminal $\alpha$ - and $\beta$-linked $N$-acetylgalactosamine (GalNAc) residues [23]. This binding is due to a specific amino acid sequence, which in this case is glutamine-proline-aspartic acid (QPD) [18]. Another ligand is LacdiNAc, which consists of GalNAc linked to N-acetylglucosamine (GlcNAc) via $\beta$ 1-4 linkage (GalNAc $\beta 1-4 G l c N A c)$ [18].

MGL is mainly expressed by macrophages as well as immature dendritic cells (iDCs) [7,18]. With the help of MGL, these antigen-presenting cells (APCs) are able to recognize pathogens and internalize glycosylated antigens in order to present them on their surface through the major histocompatibility complex classes I and II (MHCI + II) [18]. Thus, it is involved in the innate and adaptive immune response [23]. Furthermore, this receptor also plays a role in the regulation of $\mathrm{T}$ cell homeostasis [22,24]. MGL is a multifaceted receptor that can bind more than one ligand, thereby triggering different types of immune responses [22].

\subsection{MGL in Cancer}

The main ligands of MGL in cancer are truncated O-glycans including the Tn antigen ( $\alpha$-GalNAc-Ser/Thr) [18,25] and the T antigen (Galß1-3GalNAc) [26] as well as their sialylated versions [22]. The tumor antigen mucin 1 (MUC1) expresses these shortened sugar structures on its surface [27]. Moreover, MUC1 is overexpressed in many cancer types, including colorectal, cervical, and breast cancer cells [28,29], and is hypoglycosylated compared to normal epithelia [30]. The binding of MGL to the truncated glycan structures on MUC1 leads to a defective T-helper (Th) cell-mediated response as well as to a reduction of cytotoxic T lymphocytes (CTLs) [22], which are usually able to recognize foreign antigens presented via MHCI and eliminate cancer cells [31]. In addition, the tumor-associated MUC1 glycoform bearing the sialyl T antigen was shown to impair the differentiation of DCs and impede their ability to produce interleukin-12 (IL-12) [32]. IL-12 is an inflammatory cytokine that plays an important role in innate and adaptive immunity by enhancing 
natural killer (NK) cell cytotoxicity and inducing the production of interferon- $\gamma$ by T cells and NK cells [33,34]. Besides a reduction of IL-12, anti-inflammatory IL-10 production by DCs is increased in the cancer microenvironment [7], leading to impaired DC function by enhancing spontaneous apoptosis or defective antigen presentation [32]. As a result, the binding of MGL to altered glycosylation prevents an antitumor immune response, allowing cancer cells to escape the immune system.

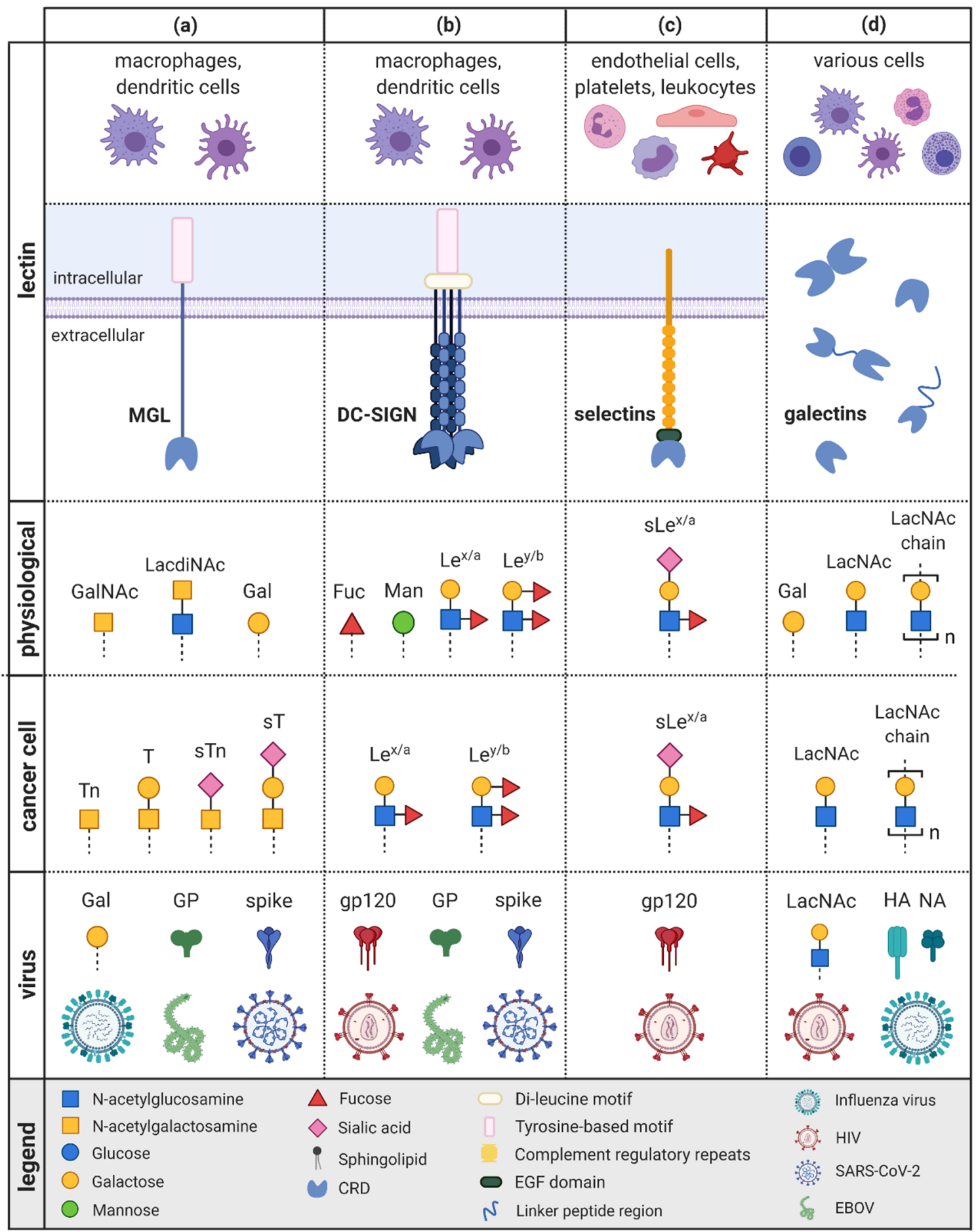

Figure 2. Lectins and their glycan interaction partner physiologically, in cancer and viral infections. The lectin subtypes MGL (a), DC-SIGN (b), and selectins (c) belong to the C-type lectin receptors (CLRs) and consist of a carbohydrate recognition domain (CRD) at the end of their extracellular domain as well as a transmembrane and a cytoplasmatic tail. 
Galectins (d) structurally possess one or two CRDs and, in part, a non-CRD domain or a linker peptide region. (a) MGL is expressed on macrophages and dendritic cells and physiologically binds galactose-terminated glycans and $N$-acetylgalactosamine (GalNAc). In cancer, MGL interacts with truncated O-glycans such as the T and Tn antigen as well as their sialylated forms sT and sTn. During viral infection, MGL binds terminal galactose-containing glycans of influenza virus, the viral envelope glycoprotein (GP) of Ebola virus (EBOV), and the highly glycosylated spike protein of SARS-CoV-2. (b) DC-SIGN is also expressed on macrophages and DCs and physiologically recognizes mannose- and fucose-containing glycans including the blood-group Lewis antigen family (Le) on pathogens. On cancer cells, DC-SIGN interacts, thus, mainly with the highly expressed Lewis glyco-epitopes. Furthermore, this lectin detects a wide range of viral glycoproteins, including high-mannose residues on the gp120 of HIV, high-mannose glycans of EBOV, as well as high-mannose and Le epitopes on the spike protein of SARS-CoV-2. (c) Selectins are found on endothelial cells, platelets, and leukocytes and recognize sialyl Le antigen $x\left(\mathrm{sLe}^{\mathrm{x}}\right)$ and its isomer sialyl Le antigen a $\left(\mathrm{sLe}^{\mathrm{a}}\right)$. The major ligands of selectins on cancer cells are thus the overexpressed sLe ${ }^{x / a}$. In the context of viral infections, the glycoprotein gp120 in HIV was found to play a key role in the interaction with L selectin on T cells. (d) Galectins are expressed by various cells of the innate as well as the adaptive immune system and physiologically bind $\beta$-galactose-containing glycoconjugates. In this context, $N$-acetyllactosamine (LacNAc) represents the minimal binding motif. Cancer cells possess a high number of terminal LacNAc as well as LacNAc chains resulting in increased affinity for most galectins. Enhanced LacNAc residues are also present in HIV infections. In addition, galectin-1 interacts with hemagglutinin (HA) and, possibly, neuraminidase (NA), two surface glycoproteins of the influenza virus. The figure was created with BioRender.com.

Some therapeutic approaches that aim to prevent the described immune escape by targeting glycan-lectin interaction are being investigated. In preclinical studies, Tn-MUC1 chimeric antigen receptor (CAR) $\mathrm{T}$ cells could control tumor growth in pancreatic cancer as well as in leukemia xenograft models without showing reactivity against normal tissue cells [35]. Other studies revealed the promising use of cancer immunotherapy involving a monoclonal antibody (5E5) that targets the aberrant Tn glycoform of MUC1 and is able to kill the tumor cell [36]. Napoletano et al. (2012) showed that an anti-MGL antibody leads to a CD8+ T cell immune response by activating different signal pathways including ERK1,2 and NF- $\mathrm{kB}$. Consequently, DCs are able to mature and trigger T cell activation [37]. The other ligand, LacdiNAc, can be used as a glyco-biomarker for, for example, colon, ovarian, and lung cancer, as elevated LacdiNAc levels have been observed on glycoproteins during tumor development [38].

\subsection{MGL in Viral Infections}

Apart from its known functions in tumor progression, MGL was found to also play an important role in the context of viral infections. Influenza virus glycans carry terminal galactose [39], and thus represent potential ligands for galactose-binding lectins such as MGL. It was observed in mice that MGL acts as an attachment and infectious entry receptor for influenza viruses into macrophages [40,41].

Furthermore, MGL interacts with the viral envelope GP of Ebola virus (EBOV), which contains an $\mathrm{O}$ glycan-rich, mucin-like domain [22,42,43]. The expression of MGL causes enhanced virus infectivity by improving viral attachment to the native cellular receptors [42]. Since MGL prefers binding to O-glycans by adding extended N-glycans, the interaction between GPs and MGL is disrupted and infectivity could be reduced [44]. Moreover, several studies showed that GP-specific neutralizing antibodies successfully protect animals from EBOV infection [45-49], which demonstrates that the viral envelope GP is a useful therapeutic target for EBOV infection. Currently, there are two approved vaccines against EBOV containing the gene of the Ebola virus that encodes for the surface GP. The first one is a recombinant vesicular stomatitis virus-based vaccine (VSV-EBOV, also known as Ervebo) $([50,51]$, reviewed in [52]); the second is the combination vaccine Ad26.ZEBOV/MVA BN Filo, available since 2020 [53].

Additionally, MGL might be a potential entry receptor for SARS-CoV-2, as it was shown that its spike protein is highly glycosylated [54] and that the glycans could serve as MGL ligands [55]. Thus, disrupting the interaction with MGL could be a beneficial therapeutic target (described in detail in [56]). 


\section{Dendritic Cell-Specific ICAM3-Grabbing Non-Integrin}

DC-SIGN belongs to the mannose type of CLR and, like MGL, is part of the type II group of CLRs. Thus, it also comprises a stalk region located extracellularly, a transmembrane domain, as well as a cytoplasmic tail $[22,57,58]$. This cytoplasmic region contains a tyrosine-based and a di-leucine motif that are important for antigen uptake [59] (Figure 2b). In addition, the CRD comprises the amino acid sequences of glutamic acid, proline, and asparagine (EPN) [60], which is responsible for the recognition of high-mannose [61] and fucose-containing glycans, including the blood-group Lewis antigen family [62,63]. DC-SIGN is mainly expressed by iDC and macrophages [64,65]. One of the main tasks of DC-SIGN is the detection, internalization, and presentation of pathogens through DCs $[66,67]$. Furthermore, DC-SIGN enables the interactions of DCs and T cells by binding to the T cell surface receptor ICAM3 [65].

\subsection{DC-SIGN in Tumor Escape and Progression}

DC-SIGN is known to bind tumor-associated glycans, the so-called Lewis antigens $\left(\mathrm{Le}^{\mathrm{x}}, \mathrm{Le}^{\mathrm{y}}, \mathrm{Le}^{\mathrm{a}}, \mathrm{Le}^{\mathrm{b}}\right)$, which are highly upregulated in cancer [68]. They consist of fucose units bound to a disaccharide of GlcNAc and galactose [7].

In colon cancer, for example, the tumor-associated carcinoembryonic antigen (CEA) is overexpressed and carries Lewis antigens. DCs bind to the overexpressed Lewis antigens on the CEAs of colorectal cancer cells but not to the CEAs of non-tumor cells. To evade an immune response, tumor cells inhibit the original functions of DCs. By interacting with DC-SIGN, Lewis antigens increase the production of IL-10 [64,69], an anti-inflammatory cytokine, which has the effect of preventing DCs from maturing. Consequently, iDCs are unable to contribute to a strong $\mathrm{T}$ cell response and $\mathrm{T}$ cell tolerance is induced instead [70], as observed in primary cutaneous $\mathrm{T}$ cell lymphoma [71]. Thus, cancer cells are able to suppress the immune response [7].

DC-SIGN is not only involved in tumor immune evasion, but also promotes tumor development. In follicular lymphoma, DC-SIGN activates the IgM follicular lymphoma $B$ cell receptor by binding to this highly mannosylated receptor, thereby leading to its activation [72]. This supports the growth of malignant B cells [73]. Moreover, DC-SIGN on macrophages interacts with semen clusterin, an overexpressed GP in human luminal breast cancer, which expresses the terminal fucosylated glycans $\left(\mathrm{Le}^{\mathrm{x}}\right.$ and $\left.\mathrm{Le}^{\mathrm{y}}\right)$ on its surface [74], thereby promoting carcinogenesis and tumor progression $[75,76]$. On the one hand, this interaction restricts the antigen presentation of macrophages, while, on the other, it stimulates the differentiation of macrophages into a pro-angiogenic type [75].

DC-SIGN serves as a promising target molecule for DC-based vaccination strategies, as demonstrated in several studies [77-79]. Targeting DCs by glycan-modified antigens or antibodies in combination with the transient deletion of Treg cells has resulted in improved antigen-specific CD4+ and CD8+ T cell responses and long-term tumor regression [80]. By using an anti-DC-SIGN antibody (hD1V1G2/G4 or AZN-D1), an antigen-specific T cell response was observed $[78,79]$. Furthermore, when DC-SIGN is blocked by a neutralizing antibody on tumor-associated macrophages in bladder cancer, these cells no longer secrete anti-inflammatory cytokines. Instead, there is increased cytotoxic activity of $\mathrm{T}$ cells against tumor cells [81].

In addition, glycan targeting of the humanized anti Le ${ }^{y} \mathrm{mAb}$ hu3S193 showed great potential due to its high specificity against $\mathrm{Le}^{\mathrm{y}}$ as well as low toxicity but lacked the significant clinical efficacy needed to justify proceeding with phase III studies. Conjugating hu3S193 could considerably enhance efficacy but would still need further optimization [82-85].

\subsection{DC-SIGN in Viral Infections}

It is known that DC-SIGN detects a wide range of viruses, including HIV [86], filoviruses [87], SARS-CoV [88], and many more [8]. However, some viruses have adapted to use DCs to evade the immune response and infect other cells. HIV, for example, attaches to DC-SIGN via high-mannose residues on gp120 glycans and uses DCs as shuttles, allow- 
ing the trans-infection of neighboring CD4+ T cells $[57,86]$. Furthermore, DCs sequester HIV virions in multivesicular bodies, enabling the virus to evade immune response [89]. The binding of HIV to DC-SIGN enhances IL-10 (anti-inflammatory cytokine) production via the ERK signaling pathway [62,90]. To prevent IL-10 induction and the impairment of DC maturation, the binding of gp120 to DC-SIGN can be inhibited by using, for example, the neutralizing human monoclonal antibody 2G12 [90,91]. In addition, it has been shown that competitive inhibitors, such as multivalent dendrimeric Lewis-type antigen-based complexes or other synthetic carbohydrate constructs, can block the binding of gp120 to DC-SIGN, whereby HIV transmission to CD4+ T cells is prevented [92-95]. Moreover, the glycomimetic DC-SIGN ligand Polyman26 can inhibit DC-SIGN-mediated HIV infection [96]. Chloroquine [97] as well as dextran and gp120 antagonists [98] show a similar effect. siRNAs directed against DC-SIGN may also prevent the initial binding of HIV-1 to the receptor [99]. Moreover, it was demonstrated that semen clusterin is not only a promising ligand for DC-SIGN in cancer, it also abolishes the binding of HIV-1 to DC-SIGN by high-affinity binding fucose-rich glycans on semen clusterin to DC-SIGN [74].

DC-SIGN is well known for binding mannose-rich carbohydrates [61] that are present on the surface of filoviruses [100,101], particularly in the mucin domain of GP1, a subunit of the GP, on the Ebola virus. Since this domain is characterized by a high content of Nand O-linked glycosylation, it is, among other factors, responsible for the immune evasion of EBOV as well as impaired immune activation $[102,103]$. Some studies showed that DC-SIGN enhances the infection with the Ebola virus but is not directly involved in the entry of the virus $[101,104]$. Moreover, like in HIV, trans-infection is also possible through DC-SIGN [87]. Lasala et al. (2003) developed a glycodendritic structure called BH30sucMan which inhibits DC-SIGN-mediated EBOV infection by impeding their interaction [105]. In general, it was shown that glycodendrinanoparticles are able to mimic pathogens, thereby inhibiting Ebola infection of DCs by blocking viral binding to DC-SIGN [106].

Furthermore, DC-SIGN may play a role in the viral entry of SARS-CoV-2 [55] and as a potent trans-receptor [107] by binding high-mannose and Lewis epitopes on the spike protein. Recently, it was demonstrated that the same glycomimetic antagonist of DC-SIGN used against HIV, Polyman26, inhibits the interaction of the spike protein with the lectin receptor and thus hinders DC-SIGN-mediated SARS-CoV-2 trans-infections [107].

\section{Selectins}

Selectins belong to group IV of the CLRs and can be divided into three subgroups (E-, L-, and P-selectins) depending on their expression pattern (endothelial cells, leukocytes, or platelets) $[108,109]$. They consist of a N-terminal C-type lectin domain, an epidermal growth factor (EGF)-like domain, several regulatory short consensus repeats (SCRs), as well as a transmembrane domain and a cytoplasmic tail [110]. All three receptors recognize a minimal recognition pattern called sialyl Lewis antigen $\mathrm{x}\left(\mathrm{sLe}^{\mathrm{x}}\right)$ as well as its isomer, sialyl Lewis antigen a (sLe $\left.{ }^{\mathrm{a}}\right)$, comprising sialic acid and fucose (Sia $\alpha 2,3 \mathrm{Gal} \beta 1,4(\mathrm{Fuc} \alpha 1,4 / 3)$ GlcNAc) $[111,112]$ (Figure 2c). SLe ${ }^{x}$ is presented by several GPs including the P-selectin glycoprotein ligand-1 (PSGL-1), which is a key ligand for all selectins [113].

The main difference between the three selectins lies in their expression patterns: E-selectin is expressed on stimulated endothelial cells, whereby the expression is induced upon inflammatory cytokines and can take several hours [114]. P-selectin, on the other hand, is constitutively expressed in platelets and endothelial cells and is rapidly translocated to the cell surface during inflammation [114]. Meanwhile, L-selectin is constitutively expressed on leukocytes [110] but is cleaved by the metalloproteinase ADAM17 upon cell activation in a process called L-selectin shedding [115,116].

All three receptors are suggested to be essential for inflammation [117]. By binding to glycan structures on leukocytes, the endothelial P- and E-selectins promote an initial tethering and rolling of leukocytes resulting in leukocyte extravasation [118-120]. L-selectin, on the other hand, might enhance inflammation by promoting leukocyte-endothelial [121] as well as leukocyte-leukocyte interactions [122]. Additionally, it was suggested that 
this binding process triggers signal transduction resulting in leukocyte integrin activation (P-selectin [123] and E-selectin [124]), cytokine secretion (P-selectin [125]), or neutrophil activation (L-selectin [126]). Moreover, it was indicated that P-selectin on platelets is involved in thrombus formation [127] and is essential for hemostasis [128,129]. L-selectin on lymphocytes promotes extravasation to lymphoid tissues by attaching to high endothelial venule cells on secondary lymphoid organs [130].

\subsection{Selectins in Cancer}

As selectins are physiologically important for the interactions involving leukocytes, platelets, or endothelial cells [109], it is not surprising that they play an essential role in tumor-promoting inflammation and cancer metastasis [131]. In particular, E-selectin was reportedly discovered to be upregulated during metastasis [132], representing an essential receptor in leukemia [133], and myeloma but also in solid tumors including pancreatic, prostate, colon, and breast carcinoma (reviewed in [134]). Moreover, there is strong evidence that the expression of $\mathrm{sLe}^{\mathrm{x}}$ and $\mathrm{sLe} \mathrm{a}^{\mathrm{a}}$ is also increased in many cancer types, for example, in gastrointestinal cancer, carcinoma or melanoma cells correlating with enhanced metastasis and poor prognosis [112,135-137]. The interaction between sLe ${ }^{\mathrm{x}}$ and E-selectin is well recognized to enhance the adhesion of cancer cells to the endothelium [138], one example being leukemic cells adhering to the bone marrow $[139,140]$. Additionally, E-selectin overexpression and the subsequent interaction with the tumor-microenvironment was shown to activate pro-survival and antiapoptotic signaling via the ERK/AKT, PI3K, NF- $\mathrm{kB}$, or Wnt pathway (reviewed in [134]), which promoted tumor progression, chemoresistance [134], and also the maintenance of cancer cell stemness [141]. In particular, its role in acute myeloid leukemia (AML) is well researched. It was discovered that AML blasts secrete inflammatory mediators leading to E-selectin upregulation [133]. This creates a protective vascular niche and induces pro-survival signaling via the AKT/NF- $\mathrm{KB} / \mathrm{mTOR}$ pathway, which promotes cancer cell survival and regeneration as well as resistance to chemotherapy [133].

While the importance of the E-selectin-sLe ${ }^{\mathrm{x}}$ interaction for promoting adhesion in tumor metastasis is well established, it is proposed that P- and L-selectin are essential for creating an inflammatory metastatic microenvironment once cancer cells intravasate and circulate in the bloodstream (reviewed in [131]). It is suggested that directly after intravasation or an initial arrest, P-selectin mediates the interaction between platelets and cancer cells, creating a tumor embolus [142]. As a consequence of cytokine and chemokine secretion, L-selectin recruits leukocytes to activated endothelial cells, which strengthens the embolus. This embolus further supports metastasis by enhancing the microvascular arrest, protecting tumor cells from immune cleavage, and promoting angiogenesis and cancer growth [131]. Moreover, recruited leukocytes can help tumor cells break the endothelial barrier and escape the bloodstream to invade other organs and tissues [143,144].

Currently, a glycomimetic of the sLe antigens named Uproleselan, or GMI-1271, seems very promising in selectively blocking the interaction between leukemic cells and E-selectin [145]. By impeding the adhesion of cancer cells to bone marrow, Uproleselan mobilizes cancer cells to the blood circulation and thus sensitizes them for chemotherapy $[133,139]$. Moreover, Uproleselan has been suggested to also inhibit pro-survival signaling and cancer cell regeneration as well as to decrease therapeutic side effects due to specific targeting (reviewed in [134]). Currently, two phase III clinical trials are ongoing to evaluate the efficacy of Uproleselan in combination with different chemotherapeutic agents in newly diagnosed (NCT03701308) and relapsed/refractory (NCT03616470) adult AML patients [146]. Furthermore, Uproleselan proved to be preclinically efficient in leukemia, myeloma, pancreatic, colon, as well as breast cancer cells [134], and is currently being tested in a phase II trial (NCT04682405) in multiple myeloma (MM) patients. Moreover, molecular biosimilars have already been developed targeting, for example, CXCR4 in addition to E-selectin (GMI-1359) [147]. 


\subsection{Selectins in Viral Infections}

In HIV, the glycoprotein gp120 was shown to play an essential role in binding the L-selectin receptor on T cells. A controversial role of L-selectin was observed in promoting HIV entry on the one hand and reducing infection on the other hand [148]. Firstly, it was discovered that the interaction with L-selectin on CD4+ T cells mediates the adhesion and subsequent entry of HIV into the host cell [148]. It could be observed that the accessory protein of HIV called Vpr was able to increase the mRNA expression in primary CD4+ T cells [149]. However, it was also shown that the shedding of L-selectin after the viral entry was essential for HIV release. Additionally, L-selectin shedding could avoid the transport of the T cells back to the lymphoid organs $[115,148]$. In this context, the HIV proteins Nef and Vpu were implied in sequestering L-selectin to reduce the cellular presentation of the receptor [150]. Inhibiting the shedding of L-selectin by inhibiting the matrix metalloproteinase ADAM17 with Batimastat was able to inhibit the release of viral particles without affecting viral entry. Therefore, blocking L-selectin shedding could potentially inhibit further HIV proliferation [148].

The protective character of $\mathrm{L}$-selectin was also observed in influenza virus and vaccinia infections, where L-selectin was required to bring CD8+ T cells to the infection site and eliminate the virus [151]. After L-selectin is shed upon T cell priming, it is possibly reexpressed when CD8+ T cells migrate to lymph nodes in order to reach virally infected organs. Genetically engineering CD8+ T cells to express non-cleavable L-selectins could promote viral clearance $[115,152]$. Thus, CAR-T cells containing a modified L-selectin receptor could represent a possible therapy. In comparison to L-selectin, the importance of E-selectin in viruses, especially HIV, is much more debated [153]. In HIV, it was shown that the Tat protein was secreted by infected cells and, once taken up by healthy cells, could lead to the upregulation of E-selectin in these cells. This upregulation was suggested to enable HIV transfection of the brain [154]. However, E-selectin does not correlate with disease progression, and Hoffman et al. (2018) proposed an increase in E-selectin in an acute inflammatory, rather than chronic, phase of HIV infection [153].

Lastly, the ligands sLe ${ }^{\mathrm{x}}$ and PSGL-1 might also be essential and could present future therapies or therapy targets. It was shown that sLe ${ }^{\mathrm{x}}$ was enhanced in infected and transcriptionally active cells, enabling higher trafficking of the cells [155]. Meanwhile, additional PSGL-1 on virus-producing cells could compete with HIV but also SARS-CoV-2 for the selectin receptors. They sterically blocked the interaction and, thus, impeded virus attachment and infectivity $[156,157]$.

\section{Galectins}

Galectins, first known as S-lectins, are a family of animal lectins the binding of which is mediated via a conserved CRD of approximately 130 amino acids [158,159]. Among the 15 galectins identified in mammals so far, 12 are also present in humans [160,161]. Depending on their presentation of CRD domains, galectins can be divided into three groups [162]. 'Prototype' galectins possess one CRD and can occur as monomers (gal-5, 7, 10) or dimers (gal-1, 2, 11, 13, 14). In addition, there are the 'tandem-repeat type' (gal-4, $6,8,9,12)$, galectins with two CRDs linked by a short linker region. The third 'chimeric type' group, which only includes gal-3, contains one CRD and one non-CRD domain [162] (Figure 2d). In this review, we mainly concentrate on gal-1,3, and 9, as these galectins are considered to play a key role in cancer as well as in the context of viral infections $[163,164]$.

Galectins exhibit affinity for $\beta$-galactose-containing glycoconjugates [158] with the minimal binding motif of $N$-acetyllactosamine (LacNAc, Gal- $\beta(1,4)$-GlcNAc) $[165,166]$. Therefore, LacNAc can occur as the terminal disaccharide of N-glycan chains or as a repeating unit in a polyglycan chain on N- or O-glycans [159,167-169]. However, the individual galectins show specificity towards certain variants of this minimum disaccharide ligand. While gal-3 preferentially binds to internal and terminal LacNAc residues of oligosaccharides, the binding of gal-1 is limited to terminal LacNAc residues [170]. In contrast, the two CRDs of gal-9 display affinity for repeated oligolactosamines as well 
as for branched N-glycans [171]. The ability to homodimerize and oligomerize enables galectins to simultaneously interact with several glycoconjugates due to bi- or multivalency [172,173]. In mammals, galectins are expressed by various immune cells, such as DCs [174], macrophages [175], mast cells [176], eosinophils [177,178], neutrophils [179], NK cells [180], B, and T cells [181-184]. It is possible that individual galectins have a wide range of effects on different cell types, but also that multiple galectins bind to and act on the same cell [185].

Galectins have a multitude of functions both intracellularly [186] and extracellularly [187-190]. Therefore, galectins are responsible for the regulation of important cellular processes like adhesion [191,192], differentiation [185], maturation [185], activation [192], proliferation [191,192], migration [192], trafficking [191], apoptosis [191,192], cytokine secretion $[185,191]$, and cell-cell communication $[185,191]$. As a result, human galectins play multiple roles in a wide range of physiological functions, and are often directly linked to immunity and pathological processes such as cancer and viral infection $[161,164,193]$.

\subsection{Galectins in Cancer}

Within the galectin family, gal-1, gal-3, gal-7, gal-8, gal-9, gal-10, and gal-12 have been linked to cancer so far [194]. In the following sections, the focus will be on gal-1, gal-3, and gal-9, as these galectins are among the most involved galectins in cancer hallmarks, according to current research [163].

\subsubsection{Galectin-1 and Galectin-3}

Altered galectin expression is frequently present in cancer, with gal- 1 being overexpressed in most cancer types, whereas expression differs more strongly in gal-3 (reviewed in [195]). In addition, tumor cells display an increase in the size and branching of N-glycan structures [13], leading to more terminal LacNAc residues and poly-LacNAc chains. This results in additional ligands for galectins, causing an enhanced affinity for most galectins, including gal-1, gal-3, and gal-9 [196-198].

According to Girotti et al. (2020), gal-1 and gal-3 promote proliferation, immune escape, replicative immortality, cell death resistance, angiogenesis, invasion, and metastasis. In addition, these galectins have both a promoting and an inhibitory effect on tumor suppressors such as TP53 [199-201]. Moreover, studies showed that gal-1 exhibits both effects in tumor-promoting inflammation [202,203] and gal-3 in genomic instability and mutation [204,205]. Furthermore, gal-3 supports tumor-promoting inflammation and impedes the deregulation of cellular energetics [206,207].

Blocking gal-1 and gal-3 with peptide- and carbohydrate-derived or small-moleculespecific inhibitors revealed a restraining effect on tumor growth, angiogenesis, and metastasis in preclinical as well as clinical studies (reviewed in [194]). Inhibition of gal-3 was found to disrupt multidrug resistance mechanisms leading to increased sensitivity to chemotherapeutic agents $[208,209]$. So far, different galectin inhibitors have been investigated in combination with chemotherapy, radiotherapy, or other immune interventions in various clinical trials [194,210-212]. In a phase II clinical trial (NCT00110721), the galectin inhibitor Davanat with high selectivity for gal-1 but only moderate selectivity towards gal-3 [213,214] showed an increase in life expectancy as well as a reduction in serious side effects in colorectal cancer patients [215]. Phase III of this clinical trial seems to have been accepted by the FDA but has not yet started [210]. Moreover, other phase II clinical studies (NCT00514696, NCT01681823) could confirm an increase in therapeutic effect [194,210]. In addition, there is an ongoing phase I trial (NCT02575404) of a galectin inhibitor in combination with a $\mathrm{T}$ cell checkpoint inhibitor. Overall, the large number of trials in this area indicate that targeting these galectins is still highly relevant as a potential cancer therapy.

\subsubsection{Galectin-9}

In contrast to gal- 1 and gal-3, the expression of gal-9 in cancer tissues is still understudied. Up to now, gal-9 expression has been found to be downregulated in most 
tumors [216-220], excluding oral cancer [221], pancreatic cancer [222], and Hodgkin's lymphoma [223]. Intracellular and extracellular gal-9 has multiple functions. While intracellular gal-9 was found to be involved in cell adhesion, migration, proliferation, apoptosis, and trafficking, extracellular gal-9 was recently identified to be a multi-faceted immunomodulator [224]. On the one hand, extracellular gal-9 downregulates the response of effector Th1 cells and induces their cell death by specifically binding to $\mathrm{T}$ cell immunoglobulin and mucin domain-containing molecule 3 (TIM-3), a membrane protein on differentiated Th1 cells [225-229]. On the other hand, extracellular gal-9 showed an involvement in DC maturation and increased the differentiation and suppressive activity of regulatory T cells [230].

This two-sided role of gal-9 is also reflected in tumors [211]. So far, it has been shown that gal-9 promotes immune escape, angiogenesis, and tumor growth, while on the other hand, gal-9 also inhibits tumor energy metabolism [163]. Existing literature indicates that, depending on which ligand gal-9 interacts with on T cells, the APCs or tumor cells it exhibits either an antitumor effect or promotes tumor activity [211]. The binding of gal-9 to N-glycans on TIM-3 in myeloid leukemia cells restricts tumor growth and metastasis [231]. Similarly, immunohistochemical studies of samples from patients with hepatocellular carcinoma, breast cancer, melanoma, and cervical squamous-cell carcinoma suggest that gal-9 suppresses metastasis and, thus, may be used as a marker for the metastatic potential of these tumors $[217,219,220,232]$. In contrast, the results of mouse models (in vivo/in vitro) suggested an apoptotic effect of gal-9 on tumor cells in chronic myeloid leukemia (CML), malignant melanomas, and different gastrointestinal and urogenital tumors [233-242]. Furthermore, Zhang et al. (2020) identified that intracellular as well as extracellular gal-9 plays an important role in promoting immunosuppressive myeloid cells in tumors. It was confirmed that high levels of gal-9 in the tumor tissue or serum of cancer patients are associated with an unfavorable outcome [224]. Recently, a new molecular pathway has been uncovered in which gal-9 plays a key role in combination with PD-1, making it a target for cancer immunotherapy [243]. Gal-9 was found to interact with PD-1 to inhibit the apoptosis of TIM-3 T cells and further promote the persistence of exhausted T cells in tumors. Furthermore, gal- 9 expression was shown to be upregulated by interferon- $\beta$ and secretion by a combination of interferon- $\beta / \gamma$ [243]. Moreover, it was demonstrated in vitro that the inhibition of gal-9-TIM-3 interaction using the anti-gal-9 antibody RG9-1 leads to the suppression of gal-9-induced T cell death. However, only the combination of this gal-9 antibody with an agonistic antibody against the co-stimulatory receptor GITR (glucocorticoid-induced tumor necrosis factor receptor-related protein) exhibited an antitumor effect and prolonged survival [243]. There was also prior evidence that the inhibition of the TIM-3-gal-9 pathway leads to increased T cell proliferation and the secretion of cytokines [227]. Therefore, LYT-200, a monoclonal antibody targeting gal-9, is currently being tested in phase I/II of a clinical trial (NCT04666688) in combination with chemotherapy or anti-PD-1 in patients with metastatic solid tumors. Taken together, previous insights in this field suggest that targeting gal-9 is an effective and promising strategy for cancer immunotherapy.

\subsection{Galectins in Viral Infections}

While so far gal-1, 3, 8, and 9 were reported to play a key role in virus attachment, entry, replication, and immune response (reviewed in [164]), we focus here only on gal-1, gal-3, and gal-9 in HIV and influenza virus infections.

\subsubsection{Galectin-1}

The role of gal-1 in HIV infection is reflected by its expression in the thymus [244,245] and lymph nodes as well as its secretion by activated CD8+ T lymphocytes, which are present at high levels in HIV-1-positive patients [246]. One key function of gal-1 is the stabilization of HIV-1 attachment to host cells which, by shortening the time required to establish infection, may facilitate HIV-1 infectivity [246,247]. Moreover, the altered surface 
glycosylation of HIV-1 infected T cells, such as the augmented expression of LacNAc residues, leads to the enhanced susceptibility to gal-1-induced cell death of peripheral blood lymphocytes and may be linked to T cell loss in AIDS [248]. Inhibition of gal-1 with three lactoside derivatives was successful in blocking gal-1-mediated, increased HIV-1 attachment and infectivity [249].

Gal-1 exhibits a completely opposite mode of action in influenza virus infection. Gal-1 is assumed to inhibit influenza virus infection by binding to hemagglutinin and, possibly, neuraminidase, two important surface GPs of this virus that are essential for virus attachment and release, respectively [250]. A study in mice revealed that intranasal treatment with human-recombinant gal-1 could reduce viral load, inflammation, and apoptosis in the lungs [250]. Thus, the administration of gal-1 may represent a new strategy in the therapy of influenza viruses.

\subsubsection{Galectin-3}

In the search for a link between HIV and gal-3, it was discovered that the Tat protein of HIV-1, which is crucial for viral replication, induces the upregulation of gal-3 in various human cell types [251,252]. Later, gal-3 was found to facilitate HIV-1 release by stabilizing proteins important for this process [253]. In contrast, gal-3 was also observed to promote the elimination of HIV-1-infected macrophages through caspase-independent cell death [254].

To date, not much is known about the effect of gal-3 on influenza virus infection. Anthraquinones such as aloe-emodin exhibit antiviral activity as well as an inhibitory effect on the replication of various viruses [255-258]. In the case of influenza virus infection, it was observed that treatment with aloe-emodin led to an upregulation of gal-3 [259]. This recombinant gal-3 in turn increased the expression of antiviral genes such as RNAdependent protein kinase and interferon- $\beta / \gamma$ [259].

SARS-CoV- 2 belongs to the genus $\beta$-coronaviridae. It was found that the key domain of the spike protein in this genus is morphologically very close to human gal-3 [260,261]. Consequently, gal-3 inhibitors could potentially hamper virus entry [262]. Furthermore, gal-3 inhibition was demonstrated to suppress host inflammatory response [262-264]. On top of that, the gal-3 inhibitor TD-139, currently being tested in phase IIb clinical trials, showed promising results [265]. In this context, it should be noted that a gal-1 inhibitor against COVID-19 is in development, which is expected to perturb viral attachment but also to manipulate cytokine release [262].

\subsubsection{Galectin-9}

Gal-9 promotes HIV-1 transcription and replication through alternative glycosylation [266] and T cell receptor-dependent ERK signaling as well as CREB pathways [267]. Infection with HIV-1 increases gal-9 levels, which may contribute to NK cell dysfunction in chronic HIV infection [268]. Furthermore, it was found that gal-9 regulates the host restriction factor p21 [269], which modulates HIV transcription in patients receiving antiretroviral therapy [270]. As a result, Abdel-Mohsen et al. (2016) showed that a recombinant form of gal-9 could reverse the latency of HIV in vitro. In addition, the glycosylation of infected host cells was found to mediate signals that could determine the infectivity of HIV [271].

In influenza virus infections, it could be observed that infected patients have a higher gal-9 expression in plasma, making gal-9 a potential novel biomarker in this field [272]. Moreover, it was revealed that the inhibition of gal-9 signaling leads to the activation of the virus-specific CD8 T cell response. This caused the increased production of virus-specific antibodies and supported rapid virus clearance [273].

\section{Conclusions}

In this review we have considered the glycan-lectin interactions for the four different lectin subtypes MGL, DC-SIGN, selectins, and galectins physiologically and both in cancer and in viral infections. We have summarized some approaches to disrupt them in order to 
see whether there are commonalities in the interactions between cancer and viral infections. The main findings for the four lectin subtypes are:

MGL binds galactose-terminated glycans and GalNAc, which mediates the internalization and presentation of pathogenic molecules during immune response. However, cancer cells and viruses have evolved strategies to avoid the initial role of MGL in immunity activation and even use MGL to their advantage. In cancer, MGL interacts with truncated O-glycans, namely the (s)Tn and (s)T antigen on glycan carriers like MUC1. This increases anti-inflammatory cytokine levels and impairs the differentiation of DCs and the Th cellmediated response, causing the immune evasion of cancer cells. Currently, Tn-MUC-1 CAR-T cells and cancer vaccines targeting Tn-MUC1 are investigated preclinically. In viral infections, on the other hand, MGL was shown to interact with terminal galactose on the influenza virus or the spike protein of SARS-CoV-2, functioning as a potential entry receptor. Moreover, it interacts with the viral envelope protein of GP on EBOV enhanced infectivity, which could be reduced with the injection of GP-neutralizing antibodies.

DC-SIGN binds to high-mannose and fucose glycans like the Lewis-antigen family, which promotes the detection of pathogens and T cell presentation. In cancer cells, overexpressed Lewis antigens on glycan carriers like CEA interact with DC-SIGN. The effect is similar to that of MGL. Immunosuppressive cytokines prevent DC maturation, which makes them unable to promote a T cell response against cancer cells. Apart from immune evasion, the DC-SIGN-glycan interaction promotes cancer carcinogenesis and tumor progression. Several therapeutic methods target the DC-SIGN receptor using glycanmodified antigens and antibodies either against DC-SIGN or Ley. During viral infections, DC-SIGN was shown to bind gp120 on HIV using DC as a shuttle for the trans-infection of CD4+ T cells. Moreover, the GP1 of EBOV binding to DC-SIGN could support immune evasion, thus enhancing viral infection. Glycodendritic structures mimicking pathogens could block these viral interactions with DC-SIGN. Lastly, the glycomimetic antagonist of DC-SIGN, named Polyman26, was shown to inhibit both DC-SIGN-mediated SARS-CoV-2 and HIV infection.

All three selectin subtypes (E-selectin, L-selectin, and P-selectin) bind sLe ${ }^{\mathrm{x} / \mathrm{a}}$ carried, for example, by PSGL-1 promoting inflammation and hemostasis. In cancer, selectins binding to overexpressed sLe ${ }^{\mathrm{x}}$ were shown to be essential for enabling cancer cell attachment during metastasis as well as for creating a metastatic tumor embolus promoting immune evasion. Currently, one of the most promising therapies is the sLe ${ }^{\mathrm{x}}$-glycomimetic Uproleselan, which blocks E-selectin and is being tested in two phase III studies. Meanwhile, the importance of L-selectin in virus is a little more researched, especially in HIV. While the interaction with gp120 was shown to promote HIV entry, the shedding of the receptor was required for viral release. In influenza virus infection, L-selectin was required for the CD8+ $\mathrm{T}$ cells to eliminate the virus. Therefore, current approaches try to inhibit L-selectin shedding by using Batimastat or genetically engineered CD8+ T cells. Moreover, the addition of selectin ligands like PSGL-1 could compete with viruses like HIV or SARS-CoV-2 for the receptors and impede infectivity. Thus, it might also be interesting to test whether the sLe $^{\mathrm{x}}$-glycomimetic Uproleselan has an effect in viral infections.

Galectins interacting with LacNAc and $\beta$-galactose-glycoconjugates were shown to be essential in many cellular processes ranging from the maintenance of cell homeostasis to immune and inflammatory responses. In cancer, the increased branching of N-glycans and, partially, galectin overexpression enhances galectin affinity to the cancer cells promoting immune escape and tumor proliferation as well as a range of other cancer hallmarks. However, the interaction with galectins also exhibited antitumor effects depending on the specific glycan ligands. A series of clinical trials testing peptide-derived, carbohydrate-derived, or small molecule gal- 1 and gal-3 inhibitors, some in combination with chemotherapy or radiotherapy, show promise to block the interaction. Moreover, recent approaches indicate that the inhibition of gal-9 combined with other therapeutic modalities is a promising strategy in cancer immunotherapy. In viral infections, galectins have a more controversial role. While gal-1 and gal-3 interactions with viral GPs were shown to facilitate attachment 
and release in HIV, they inhibited infection with the influenza virus. Thus, gal-1 was blocked in HIV and also SARS-CoV-2 to reduce the infection while, in the influenza virus infections, recombinant gal-1 was administered.

In summary, it has been established that the four lectin subtypes MGL, DC-SIGN, selectins, and galectins play an essential role in cancer and viral infections by interacting with specific glycans. However, research on the detailed mechanisms of these glycanlectin interactions and potential therapies is still at an early stage. So far, the therapeutic approaches look very promising, but it remains to be seen whether some of them will be successful in the clinical phases. While comparing the interactions between lectins and glycans in cancer and viral infections and the ways to disrupt them, we have not yet found commonalities suggesting that promising therapeutic approaches in one disease can be translated to another. Further research in this direction must be conducted.

Author Contributions: S.M.K., A.-S.H.K. and K.W. reviewed the literature and wrote the manuscript. S.M.K., A.-S.H.K. and K.W. contributed equally to the article and approved the submitted version. H.B. guided the writing process. All authors discussed the review and contributed to the final manuscript. All authors have read and agreed to the published version of the manuscript.

Funding: The APC was funded by Max Planck Society.

Acknowledgments: The authors would like to thank Anna Beer for her support regarding literature research and review structure as well as Tobias Krumpf for critically reviewing the manuscript. Furthermore, the authors are grateful to Julia Köberle and Benjamin Karrer for constructive discussions.

Conflicts of Interest: The authors declare that the research was conducted in the absence of any commercial or financial relationships that could be construed as a potential conflict of interest.

\begin{tabular}{|c|c|}
\hline AML & acute myeloid leukemia \\
\hline $\mathrm{APC}$ & antigen-presenting cell \\
\hline CAR & chimeric antigen receptor \\
\hline CEA & carcinoembryonic antigen \\
\hline CLR & C-type lectin receptor \\
\hline CML & chronic myeloid leukemia \\
\hline CRD & carbohydrate recognition domain \\
\hline CTL & cytotoxic T-lymphocyte \\
\hline CTLD & C-type lectin-like domain \\
\hline DC & dendritic cell \\
\hline DC-SIGN & DC-specific intracellular adhesion molecule 3-grabbing nonintegrin \\
\hline EBOV & Ebola virus \\
\hline EGF & epidermal growth factor \\
\hline GalNAc & $\alpha-N$-acetylgalactosamine \\
\hline GP & glycoprotein \\
\hline HIV & human immunodeficiency virus \\
\hline ICAM3 & intracellular adhesion molecule 3 \\
\hline iDC & immature dendritic cell \\
\hline IL & interleukin \\
\hline LacNAc & $N$-acetyllactosamine \\
\hline Le & Lewis antigen \\
\hline MGL & macrophage galactose-binding lectin \\
\hline MHC & major histocompatibility complex \\
\hline MUC1 & mucin 1 \\
\hline NK cell & natural killer cell \\
\hline PSGL-1 & P-selectin glycoprotein ligand-1 \\
\hline SARS-CoV-2 & severe acute respiratory syndrome coronavirus 2 \\
\hline SCR & short consensus repeat \\
\hline Th cell & T-helper cell \\
\hline TIM-3 & T cell immunoglobulin and mucin-domain containing 3 \\
\hline
\end{tabular}




\section{References}

1. Alberts, B.; Johnson, A.D.; Lewis, J.; Morgan, D.; Raff, M.; Roberts, K.; Walter, P. Molecular Biology of the Cell; Garland Science: New York, NY, USA, 2014.

2. Varki, A.; Kannagi, R.; Toole, B.; Stanley, P. Glycosylation Changes in Cancer. In Essentials Glycobiology, 3rd ed.; Cold Spring Harbor: New York, NY, USA, 2015.

3. Kaltner, H.; Gabius, H.J. Sensing Glycans as Biochemical Messages by Tissue Lectins: The Sugar Code at Work in Vascular Biology. Thromb. Haemost. 2019, 119, 517-533. [CrossRef] [PubMed]

4. Lu, G.; Crihfield, C.L.; Gattu, S.; Veltri, L.M.; Holland, L.A. Capillary Electrophoresis Separations of Glycans. Chem. Rev. 2018, 118, 7867-7885. [CrossRef] [PubMed]

5. Cummings, R.D.; Schnaar, R.L.; Esko, J.D.; Drickamer, K.; Taylor, M.E. Principles of Glycan Recognition, 3rd ed.; Cold Spring Harbor Laboratory Press: New York, NY, USA, 2015.

6. Cagnoni, A.J.; Pérez Sáez, J.M.; Rabinovich, G.A.; Mariño, K.V. Turning-Off Signaling by Siglecs, Selectins, and Galectins: Chemical Inhibition of Glycan-Dependent Interactions in Cancer. Front. Oncol. 2016, 6, 109. [CrossRef]

7. RodrÍguez, E.; Schetters, S.T.T.; van Kooyk, Y. The tumour glyco-code as a novel immune checkpoint for immunotherapy. Nat. Rev. Immunol. 2018, 18, 204-211. [CrossRef] [PubMed]

8. Van Breedam, W.; Pöhlmann, S.; Favoreel, H.W.; de Groot, R.J.; Nauwynck, H.J. Bitter-sweet symphony: Glycan-lectin interactions in virus biology. FEMS Microbiol. Rev. 2014, 38, 598-632. [CrossRef]

9. Brown, G.D.; Willment, J.A.; Whitehead, L. C-type lectins in immunity and homeostasis. Nat. Rev. Immunol. 2018, 18, 374-389. [CrossRef] [PubMed]

10. Mereiter, S.; Balmaña, M.; Campos, D.; Gomes, J.; Reis, C.A. Glycosylation in the Era of Cancer-Targeted Therapy: Where Are We Heading? Cancer Cell 2019, 36, 6-16. [CrossRef] [PubMed]

11. Munkley, J.; Elliott, D.J. Hallmarks of glycosylation in cancer. Oncotarget 2016, 7, 35478-35489. [CrossRef]

12. Pinho, S.S.; Reis, C.A. Glycosylation in cancer: Mechanisms and clinical implications. Nat. Rev. Cancer 2015, 15, 540-555. [CrossRef]

13. Dube, D.H.; Bertozzi, C.R. Glycans in cancer and inflammation-Potential for therapeutics and diagnostics. Nat. Rev. Drug Discov. 2005, 4, 477-488. [CrossRef]

14. Alley, W.R., Jr.; Novotny, M.V. Glycomic analysis of sialic acid linkages in glycans derived from blood serum glycoproteins. J. Proteome Res. 2010, 9, 3062-3072. [CrossRef]

15. Suenaga, T.; Arase, H. Viral Interactions with Glycans. Glycosci. Biol. Med. 2014, 785-794. [CrossRef]

16. Bagdonaite, I.; Wandall, H.H. Global aspects of viral glycosylation. Glycobiology 2018, 28, 443-467. [CrossRef]

17. Watanabe, Y.; Bowden, T.A.; Wilson, I.A.; Crispin, M. Exploitation of glycosylation in enveloped virus pathobiology. Biochim. Biophys. Acta Gen. Subj. 2019, 1863, 1480-1497. [CrossRef] [PubMed]

18. Van Vliet, S.J.; Saeland, E.; van Kooyk, Y. Sweet preferences of MGL: Carbohydrate specificity and function. Trends Immunol. 2008, 29, 83-90. [CrossRef]

19. Zelensky, A.N.; Gready, J.E. The C-type lectin-like domain superfamily. FEBS J. 2005, 272, 6179-6217. [CrossRef]

20. Drickamer, K.; Fadden, A.J. Genomic analysis of C-type lectins. Biochem. Soc. Symp. 2002, 59-72. [CrossRef]

21. Drickamer, K. $\mathrm{Ca}^{2+}$-dependent carbohydrate-recognition domains in animal proteins. Curr. Opin. Struct. Biol. 1993, 3, 393-400. [CrossRef]

22. Zizzari, I.G.; Napoletano, C.; Battisti, F.; Rahimi, H.; Caponnetto, S.; Pierelli, L.; Nuti, M.; Rughetti, A. MGL Receptor and Immunity: When the Ligand Can Make the Difference. J. Immunol. Res. 2015, 2015, 450695. [CrossRef] [PubMed]

23. Van Vliet, S.J.; van Liempt, E.; Saeland, E.; Aarnoudse, C.A.; Appelmelk, B.; Irimura, T.; Geijtenbeek, T.B.; Blixt, O.; Alvarez, R.; van Die, I.; et al. Carbohydrate profiling reveals a distinctive role for the C-type lectin MGL in the recognition of helminth parasites and tumor antigens by dendritic cells. Int. Immunol. 2005, 17, 661-669. [CrossRef]

24. Van Vliet, S.J.; Gringhuis, S.I.; Geijtenbeek, T.B.; van Kooyk, Y. Regulation of effector T cells by antigen-presenting cells via interaction of the C-type lectin MGL with CD45. Nat. Immunol. 2006, 7, 1200-1208. [CrossRef]

25. Suzuki, N.; Yamamoto, K.; Toyoshima, S.; Osawa, T.; Irimura, T. Molecular cloning and expression of cDNA encoding human macrophage C-type lectin. Its unique carbohydrate binding specificity for Tn antigen. J. Immunol. 1996, 156, $128-135$.

26. Higashi, N.; Fujioka, K.; Denda-Nagai, K.; Hashimoto, S.; Nagai, S.; Sato, T.; Fujita, Y.; Morikawa, A.; Tsuiji, M.; Miyata-Takeuchi, M.; et al. The macrophage C-type lectin specific for galactose/ $\mathrm{N}$-acetylgalactosamine is an endocytic receptor expressed on monocyte-derived immature dendritic cells. J. Biol. Chem. 2002, 277, 20686-20693. [CrossRef] [PubMed]

27. Saeland, E.; van Vliet, S.J.; Bäckström, M.; van den Berg, V.C.; Geijtenbeek, T.B.; Meijer, G.A.; van Kooyk, Y. The C-type lectin MGL expressed by dendritic cells detects glycan changes on MUC1 in colon carcinoma. Cancer Immunol. Immunother. 2007, 56, 1225-1236. [CrossRef] [PubMed]

28. Graham, R.A.; Burchell, J.M.; Taylor-Papadimitriou, J. The polymorphic epithelial mucin: Potential as an immunogen for a cancer vaccine. Cancer Immunol. Immunother. 1996, 42, 71-80. [CrossRef] [PubMed]

29. Zaal, A.; Li, R.J.E.; Lübbers, J.; Bruijns, S.C.M.; Kalay, H.; van Kooyk, Y.; van Vliet, S.J. Activation of the C-Type Lectin MGL by Terminal GalNAc Ligands Reduces the Glycolytic Activity of Human Dendritic Cells. Front. Immunol. 2020, 11, 305. [CrossRef] [PubMed] 
30. Carlos, C.A.; Dong, H.F.; Howard, O.M.; Oppenheim, J.J.; Hanisch, F.G.; Finn, O.J. Human tumor antigen MUC1 is chemotactic for immature dendritic cells and elicits maturation but does not promote Th1 type immunity. J. Immunol. 2005, 175, $1628-1635$. [CrossRef] [PubMed]

31. Andersen, M.H.; Schrama, D.; Thor Straten, P.; Becker, J.C. Cytotoxic T cells. J. Investig. Dermatol. 2006, 126, 32-41. [CrossRef]

32. Rughetti, A.; Pellicciotta, I.; Biffoni, M.; Bäckström, M.; Link, T.; Bennet, E.P.; Clausen, H.; Noll, T.; Hansson, G.C.; Burchell, J.M.; et al. Recombinant tumor-associated MUC1 glycoprotein impairs the differentiation and function of dendritic cells. J. Immunol. 2005, 174, 7764-7772. [CrossRef]

33. Kobayashi, M.; Fitz, L.; Ryan, M.; Hewick, R.M.; Clark, S.C.; Chan, S.; Loudon, R.; Sherman, F.; Perussia, B.; Trinchieri, G. Identification and purification of natural killer cell stimulatory factor (NKSF), a cytokine with multiple biologic effects on human lymphocytes. J. Exp. Med. 1989, 170, 827-845. [CrossRef]

34. Trinchieri, G.; Wysocka, M.; D’Andrea, A.; Rengaraju, M.; Aste-Amezaga, M.; Kubin, M.; Valiante, N.M.; Chehimi, J. Natural killer cell stimulatory factor (NKSF) or interleukin-12 is a key regulator of immune response and inflammation. Prog. Growth Factor Res. 1992, 4, 355-368. [CrossRef]

35. Posey, A.D., Jr.; Schwab, R.D.; Boesteanu, A.C.; Steentoft, C.; Mandel, U.; Engels, B.; Stone, J.D.; Madsen, T.D.; Schreiber, K.; Haines, K.M.; et al. Engineered CAR T Cells Targeting the Cancer-Associated Tn-Glycoform of the Membrane Mucin MUC1 Control Adenocarcinoma. Immunity 2016, 44, 1444-1454. [CrossRef]

36. Lavrsen, K.; Madsen, C.B.; Rasch, M.G.; Woetmann, A.; Ødum, N.; Mandel, U.; Clausen, H.; Pedersen, A.E.; Wandall, H.H. Aberrantly glycosylated MUC1 is expressed on the surface of breast cancer cells and a target for antibody-dependent cell-mediated cytotoxicity. Glycoconj. J. 2013, 30, 227-236. [CrossRef]

37. Napoletano, C.; Zizzari, I.G.; Rughetti, A.; Rahimi, H.; Irimura, T.; Clausen, H.; Wandall, H.H.; Belleudi, F.; Bellati, F.; Pierelli, L.; et al. Targeting of macrophage galactose-type C-type lectin (MGL) induces DC signaling and activation. Eur. J. Immunol. 2012, 42, 936-945. [CrossRef]

38. Pirro, M.; Rombouts, Y.; Stella, A.; Neyrolles, O.; Burlet-Schiltz, O.; van Vliet, S.J.; de Ru, A.H.; Mohammed, Y.; Wuhrer, M.; van Veelen, P.A.; et al. Characterization of Macrophage Galactose-type Lectin (MGL) ligands in colorectal cancer cell lines. Biochim. Biophys. Acta (BBA) Gen. Subj. 2020, 1864, 129513. [CrossRef]

39. Basak, S.; Tomana, M.; Compans, R.W. Sialic acid is incorporated into influenza hemagglutinin glycoproteins in the absence of viral neuraminidase. Virus Res. 1985, 2, 61-68. [CrossRef]

40. Upham, J.P.; Pickett, D.; Irimura, T.; Anders, E.M.; Reading, P.C. Macrophage receptors for influenza A virus: Role of the macrophage galactose-type lectin and mannose receptor in viral entry. J. Virol. 2010, 84, 3730-3737. [CrossRef]

41. Ng, W.C.; Liong, S.; Tate, M.D.; Irimura, T.; Denda-Nagai, K.; Brooks, A.G.; Londrigan, S.L.; Reading, P.C. The macrophage galactose-type lectin can function as an attachment and entry receptor for influenza virus. J. Virol. 2014, 88, 1659-1672. [CrossRef] [PubMed]

42. Takada, A.; Fujioka, K.; Tsuiji, M.; Morikawa, A.; Higashi, N.; Ebihara, H.; Kobasa, D.; Feldmann, H.; Irimura, T.; Kawaoka, Y. Human macrophage C-type lectin specific for galactose and $\mathrm{N}$-acetylgalactosamine promotes filovirus entry. J. Virol. 2004, 78, 2943-2947. [CrossRef] [PubMed]

43. Usami, K.; Matsuno, K.; Igarashi, M.; Denda-Nagai, K.; Takada, A.; Irimura, T. Involvement of viral envelope GP2 in Ebola virus entry into cells expressing the macrophage galactose-type C-type lectin. Biochem. Biophys. Res. Commun. 2011, 407, 74-78. [CrossRef] [PubMed]

44. Fujihira, H.; Usami, K.; Matsuno, K.; Takeuchi, H.; Denda-Nagai, K.; Furukawa, J.-I.; Shinohara, Y.; Takada, A.; Kawaoka, Y.; Irimura, T. A Critical Domain of Ebolavirus Envelope Glycoprotein Determines Glycoform and Infectivity. Sci. Rep. $2018,8,5495$. [CrossRef]

45. Sano, Y.; Usami, K.; Izawa, R.; Denda-Nagai, K.; Higashi, N.; Kimura, T.; Suzuki, N.; Irimura, T. Properties of blocking and non-blocking monoclonal antibodies specific for human macrophage galactose-type C-type lectin (MGL/ClecSF10A/CD301). J. Biochem. 2007, 141, 127-136. [CrossRef]

46. Marzi, A.; Yoshida, R.; Miyamoto, H.; Ishijima, M.; Suzuki, Y.; Higuchi, M.; Matsuyama, Y.; Igarashi, M.; Nakayama, E.; Kuroda, M.; et al. Protective efficacy of neutralizing monoclonal antibodies in a nonhuman primate model of Ebola hemorrhagic fever. PLoS ONE 2012, 7, e36192. [CrossRef]

47. Corti, D.; Misasi, J.; Mulangu, S.; Stanley, D.A.; Kanekiyo, M.; Wollen, S.; Ploquin, A.; Doria-Rose, N.A.; Staupe, R.P.; Bailey, M.; et al. Protective monotherapy against lethal Ebola virus infection by a potently neutralizing antibody. Science 2016, 351, 1339-1342. [CrossRef] [PubMed]

48. Takada, A.; Ebihara, H.; Jones, S.; Feldmann, H.; Kawaoka, Y. Protective efficacy of neutralizing antibodies against Ebola virus infection. Vaccine 2007, 25, 993-999. [CrossRef] [PubMed]

49. Qiu, X.; Fernando, L.; Melito, P.L.; Audet, J.; Feldmann, H.; Kobinger, G.; Alimonti, J.B.; Jones, S.M. Ebola GP-specific monoclonal antibodies protect mice and guinea pigs from lethal Ebola virus infection. PLoS Negl. Trop. Dis. 2012, 6, e1575. [CrossRef] [PubMed]

50. FDA. First FDA-Approved Vaccine for the Prevention of Ebola Virus Disease, Marking a Critical Milestone in Public Health Preparedness and Response. Available online: https:/ / www.fda.gov/news-events/press-announcements / first-fda-approvedvaccine-prevention-ebola-virus-disease-marking-critical-milestone-public-health (accessed on 15 March 2021). 
51. Poetsch, J.H.; Dahlke, C.; Zinser, M.E.; Kasonta, R.; Lunemann, S.; Rechtien, A.; Ly, M.L.; Stubbe, H.C.; Krähling, V.; Biedenkopf, N.; et al. Detectable Vesicular Stomatitis Virus (VSV)-Specific Humoral and Cellular Immune Responses Following VSV-Ebola Virus Vaccination in Humans. J. Infect. Dis. 2019, 219, 556-561. [CrossRef]

52. Suder, E.; Furuyama, W.; Feldmann, H.; Marzi, A.; de Wit, E. The vesicular stomatitis virus-based Ebola virus vaccine: From concept to clinical trials. Hum. Vaccin. Immunother. 2018, 14, 2107-2113. [CrossRef]

53. EMA. New Vaccine for Prevention of Ebola Virus Disease Recommended for Approval in the European Union. Available online: https: / / www.ema.europa.eu/en/news/new-vaccine-prevention-ebola-virus-disease-recommended-approval-europeanunion (accessed on 15 March 2021).

54. Shajahan, A.; Supekar, N.T.; Gleinich, A.S.; Azadi, P. Deducing the N- and O-glycosylation profile of the spike protein of novel coronavirus SARS-CoV-2. bioRxiv 2020. [CrossRef]

55. Gao, C.; Zeng, J.; Jia, N.; Stavenhagen, K.; Matsumoto, Y.; Zhang, H.; Li, J.; Hume, A.J.; Mühlberger, E.; van Die, I.; et al. SARS-CoV-2 Spike Protein Interacts with Multiple Innate Immune Receptors. bioRxiv 2020. [CrossRef]

56. Gadanec, L.K.; McSweeney, K.R.; Qaradakhi, T.; Ali, B.; Zulli, A.; Apostolopoulos, V. Can SARS-CoV-2 Virus Use Multiple Receptors to Enter Host Cells? Int. J. Mol. Sci. 2021, 22, 992. [CrossRef]

57. Pöhlmann, S.; Baribaud, F.; Doms, R. DC-SIGN and DC-SIGNR: Helping hands for HIV. Trends Immunol. 2001, 22, 643-646. [CrossRef]

58. Curtis, B.M.; Scharnowske, S.; Watson, A.J. Sequence and expression of a membrane-associated C-type lectin that exhibits CD4-independent binding of human immunodeficiency virus envelope glycoprotein gp120. Proc. Natl. Acad. Sci. USA 1992, 89, 8356-8360. [CrossRef]

59. Figdor, C.G.; van Kooyk, Y.; Adema, G.J. C-type lectin receptors on dendritic cells and Langerhans cells. Nat. Rev. Immunol. 2002, 2, 77-84. [CrossRef]

60. Van Vliet, S.J.; García-Vallejo, J.J.; van Kooyk, Y. Dendritic cells and C-type lectin receptors: Coupling innate to adaptive immune responses. Immunol. Cell Biol. 2008, 86, 580-587. [CrossRef]

61. Feinberg, H.; Mitchell, D.A.; Drickamer, K.; Weis, W.I. Structural basis for selective recognition of oligosaccharides by DC-SIGN and DC-SIGNR. Science 2001, 294, 2163-2166. [CrossRef]

62. Geijtenbeek, T.B.H.; Gringhuis, S.I. Signalling through C-type lectin receptors: Shaping immune responses. Nat. Rev. Immunol. 2009, 9, 465-479. [CrossRef]

63. Pederson, K.; Mitchell, D.A.; Prestegard, J.H. Structural Characterization of the DC-SIGN-LewisX Complex. Biochemistry 2014, 53, 5700-5709. [CrossRef] [PubMed]

64. Van Gisbergen, K.P.; Aarnoudse, C.A.; Meijer, G.A.; Geijtenbeek, T.B.; van Kooyk, Y. Dendritic cells recognize tumor-specific glycosylation of carcinoembryonic antigen on colorectal cancer cells through dendritic cell-specific intercellular adhesion molecule-3-grabbing nonintegrin. Cancer Res. 2005, 65, 5935-5944. [CrossRef] [PubMed]

65. Geijtenbeek, T.B.; Torensma, R.; van Vliet, S.J.; van Duijnhoven, G.C.; Adema, G.J.; van Kooyk, Y.; Figdor, C.G. Identification of DC-SIGN, a novel dendritic cell-specific ICAM-3 receptor that supports primary immune responses. Cell 2000, 100, 575-585. [CrossRef]

66. Van Kooyk, Y.; Rabinovich, G.A. Protein-glycan interactions in the control of innate and adaptive immune responses. Nat. Immunol. 2008, 9, 593-601. [CrossRef]

67. Guo, Y.; Feinberg, H.; Conroy, E.; Mitchell, D.A.; Alvarez, R.; Blixt, O.; Taylor, M.E.; Weis, W.I.; Drickamer, K. Structural basis for distinct ligand-binding and targeting properties of the receptors DC-SIGN and DC-SIGNR. Nat. Struct Mol. Biol. 2004, 11, 591-598. [CrossRef]

68. Blanas, A.; Sahasrabudhe, N.M.; Rodríguez, E.; van Kooyk, Y.; van Vliet, S.J. Fucosylated Antigens in Cancer: An Alliance toward Tumor Progression, Metastasis, and Resistance to Chemotherapy. Front. Oncol. 2018, 8, 39. [CrossRef]

69. Nonaka, M.; Ma, B.Y.; Murai, R.; Nakamura, N.; Baba, M.; Kawasaki, N.; Hodohara, K.; Asano, S.; Kawasaki, T. Glycosylationdependent interactions of C-type lectin DC-SIGN with colorectal tumor-associated Lewis glycans impair the function and differentiation of monocyte-derived dendritic cells. J. Immunol. 2008, 180, 3347-3356. [CrossRef] [PubMed]

70. Jonuleit, H.; Schmitt, E.; Schuler, G.; Knop, J.; Enk, A.H. Induction of interleukin 10-producing, nonproliferating CD4(+) T cells with regulatory properties by repetitive stimulation with allogeneic immature human dendritic cells. J. Exp. Med. 2000, 192, 1213-1222. [CrossRef] [PubMed]

71. Schlapbach, C.; Ochsenbein, A.; Kaelin, U.; Hassan, A.S.; Hunger, R.E.; Yawalkar, N. High numbers of DC-SIGN+ dendritic cells in lesional skin of cutaneous T-cell lymphoma. J. Am. Acad. Dermatol. 2010, 62, 995-1004. [CrossRef] [PubMed]

72. Amin, R.; Mourcin, F.; Uhel, F.; Pangault, C.; Ruminy, P.; Dupré, L.; Guirriec, M.; Marchand, T.; Fest, T.; Lamy, T.; et al. DCSIGN-expressing macrophages trigger activation of mannosylated IgM B-cell receptor in follicular lymphoma. Blood 2015, 126, 1911-1920. [CrossRef]

73. Burger, J.A.; Wiestner, A. Targeting B cell receptor signalling in cancer: Preclinical and clinical advances. Nat. Rev. Cancer 2018, 18, 148-167. [CrossRef] [PubMed]

74. Sabatte, J.; Faigle, W.; Ceballos, A.; Morelle, W.; Rodríguez Rodrígues, C.; Remes Lenicov, F.; Thépaut, M.; Fieschi, F.; Malchiodi, E.; Fernández, M.; et al. Semen Clusterin Is a Novel DC-SIGN Ligand. J. Immunol. 2011, 187, 5299-5309. [CrossRef] [PubMed] 
75. Merlotti, A.; Malizia, A.L.; Michea, P.; Bonte, P.-E.; Goudot, C.; Carregal, M.S.; Nuñez, N.; Sedlik, C.; Ceballos, A.; Soumelis, V.; et al. Aberrant fucosylation enables breast cancer clusterin to interact with dendritic cell-specific ICAM-grabbing non-integrin (DC-SIGN). Oncoimmunology 2019, 8, e1629257. [CrossRef] [PubMed]

76. Tellez, T.; Garcia-Aranda, M.; Redondo, M. The Role of Clusterin in Carcinogenesis and its Potential Utility as Therapeutic Target. Curr. Med. Chem. 2016, 23, 4297-4308. [CrossRef]

77. Kretz-Rommel, A.; Qin, F.; Dakappagari, N.; Torensma, R.; Faas, S.; Wu, D.; Bowdish, K.S. In vivo targeting of antigens to human dendritic cells through DC-SIGN elicits stimulatory immune responses and inhibits tumor growth in grafted mouse models. J. Immunother. 2007, 30, 715-726. [CrossRef] [PubMed]

78. Pereira, C.F.; Torensma, R.; Hebeda, K.; Kretz-Rommel, A.; Faas, S.J.; Figdor, C.G.; Adema, G.J. In vivo targeting of DC-SIGNpositive antigen-presenting cells in a nonhuman primate model. J. Immunother. 2007, 30, 705-714. [CrossRef] [PubMed]

79. Tacken, P.J.; de Vries, I.J.M.; Gijzen, K.; Joosten, B.; Wu, D.; Rother, R.P.; Faas, S.J.; Punt, C.J.A.; Torensma, R.; Adema, G.J.; et al. Effective induction of naive and recall T-cell responses by targeting antigen to human dendritic cells via a humanized anti-DC-SIGN antibody. Blood 2005, 106, 1278-1285. [CrossRef]

80. Unger, W.W.; Mayer, C.T.; Engels, S.; Hesse, C.; Perdicchio, M.; Puttur, F.; Streng-Ouwehand, I.; Litjens, M.; Kalay, H.; Berod, L.; et al. Antigen targeting to dendritic cells combined with transient regulatory $\mathrm{T}$ cell inhibition results in long-term tumor regression. Oncoimmunology 2015, 4, e970462. [CrossRef]

81. Hu, B.; Wang, Z.; Zeng, H.; Qi, Y.; Chen, Y.; Wang, T.; Wang, J.; Chang, Y.; Bai, Q.; Xia, Y.; et al. Blockade of DC-SIGN ${ }^{+}$ Tumor-Associated Macrophages Reactivates Antitumor Immunity and Improves Immunotherapy in Muscle-Invasive Bladder Cancer. Cancer Res. 2020, 80, 1707-1719. [CrossRef]

82. Boghaert, E.R.; Sridharan, L.; Armellino, D.C.; Khandke, K.M.; DiJoseph, J.F.; Kunz, A.; Dougher, M.M.; Jiang, F.; Kalyandrug, L.B.; Hamann, P.R.; et al. Antibody-targeted chemotherapy with the calicheamicin conjugate hu3S193-N-acetyl gamma calicheamicin dimethyl hydrazide targets Lewisy and eliminates Lewisy-positive human carcinoma cells and xenografts. Clin. Cancer Res. 2004, 10, 4538-4549. [CrossRef] [PubMed]

83. Krug, L.M.; Milton, D.T.; Jungbluth, A.A.; Chen, L.-C.; Quaia, E.; Pandit-Taskar, N.; Nagel, A.; Jones, J.; Kris, M.G.; Finn, R.; et al. Targeting Lewis Y (Ley) in Small Cell Lung Cancer with a Humanized Monoclonal Antibody, hu3S193: A Pilot Trial Testing Two Dose Levels. J. Thorac. Oncol. 2007, 2, 947-952. [CrossRef]

84. Scott, A.M.; Tebbutt, N.; Lee, F.-T.; Cavicchiolo, T.; Liu, Z.; Gill, S.; Poon, A.M.T.; Hopkins, W.; Smyth, F.E.; Murone, C.; et al. A Phase I Biodistribution and Pharmacokinetic Trial of Humanized Monoclonal Antibody Hu3s193 in Patients with Advanced Epithelial Cancers that Express the Lewis-Y Antigen. Clin. Cancer Res. 2007, 13, 3286-3292. [CrossRef] [PubMed]

85. Smaletz, O.; Diz, M.D.; do Carmo, C.C.; Sabbaga, J.; Cunha-Junior, G.F.; Azevedo, S.J.; Maluf, F.C.; Barrios, C.H.; Costa, R.L.; Fontana, A.G.; et al. A phase II trial with anti-Lewis-Y monoclonal antibody (hu3S193) for the treatment of platinum resistant/refractory ovarian, fallopian tube and primary peritoneal carcinoma. Gynecol. Oncol. 2015, 138, 272-277. [CrossRef]

86. Geijtenbeek, T.B.; Kwon, D.S.; Torensma, R.; van Vliet, S.J.; van Duijnhoven, G.C.; Middel, J.; Cornelissen, I.L.; Nottet, H.S.; KewalRamani, V.N.; Littman, D.R.; et al. DC-SIGN, a dendritic cell-specific HIV-1-binding protein that enhances trans-infection of T cells. Cell 2000, 100, 587-597. [CrossRef]

87. Alvarez, C.P.; Lasala, F.; Carrillo, J.; Muñiz, O.; Corbí, A.L.; Delgado, R. C-type lectins DC-SIGN and L-SIGN mediate cellular entry by Ebola virus in cis and in trans. J. Virol. 2002, 76, 6841-6844. [CrossRef]

88. Marzi, A.; Gramberg, T.; Simmons, G.; Möller, P.; Rennekamp, A.J.; Krumbiegel, M.; Geier, M.; Eisemann, J.; Turza, N.; Saunier, B.; et al. DC-SIGN and DC-SIGNR interact with the glycoprotein of Marburg virus and the $\mathrm{S}$ protein of severe acute respiratory syndrome coronavirus. J. Virol. 2004, 78, 12090-12095. [CrossRef] [PubMed]

89. Hodges, A.; Sharrocks, K.; Edelmann, M.; Baban, D.; Moris, A.; Schwartz, O.; Drakesmith, H.; Davies, K.; Kessler, B.; McMichael, A.; et al. Activation of the lectin DC-SIGN induces an immature dendritic cell phenotype triggering Rho-GTPase activity required for HIV-1 replication. Nat. Immunol. 2007, 8, 569-577. [CrossRef] [PubMed]

90. Shan, M.; Klasse, P.J.; Banerjee, K.; Dey, A.K.; Iyer, S.P.; Dionisio, R.; Charles, D.; Campbell-Gardener, L.; Olson, W.C.; Sanders, R.W.; et al. HIV-1 gp120 mannoses induce immunosuppressive responses from dendritic cells. PLoS Pathog. 2007, 3, e169. [CrossRef] [PubMed]

91. Sanders, R.W.; Venturi, M.; Schiffner, L.; Kalyanaraman, R.; Katinger, H.; Lloyd, K.O.; Kwong, P.D.; Moore, J.P. The mannosedependent epitope for neutralizing antibody $2 \mathrm{G} 12$ on human immunodeficiency virus type 1 glycoprotein gp120. J. Virol. 2002, 76, 7293-7305. [CrossRef]

92. Garcia-Vallejo, J.J.; Koning, N.; Ambrosini, M.; Kalay, H.; Vuist, I.; Sarrami-Forooshani, R.; Geijtenbeek, T.B.; van Kooyk, Y. Glycodendrimers prevent HIV transmission via DC-SIGN on dendritic cells. Int. Immunol. 2013, 25, 221-233. [CrossRef]

93. Martínez-Avila, O.; Bedoya, L.M.; Marradi, M.; Clavel, C.; Alcamí, J.; Penadés, S. Multivalent manno-glyconanoparticles inhibit DC-SIGN-mediated HIV-1 trans-infection of human T cells. Chembiochem 2009, 10, 1806-1809. [CrossRef]

94. Sattin, S.; Daghetti, A.; Thépaut, M.; Berzi, A.; Sánchez-Navarro, M.; Tabarani, G.; Rojo, J.; Fieschi, F.; Clerici, M.; Bernardi, A. Inhibition of DC-SIGN-Mediated HIV Infection by a Linear Trimannoside Mimic in a Tetravalent Presentation. ACS Chem. Biol. 2010, 5, 301-312. [CrossRef]

95. Varga, N.; Sutkeviciute, I.; Ribeiro-Viana, R.; Berzi, A.; Ramdasi, R.; Daghetti, A.; Vettoretti, G.; Amara, A.; Clerici, M.; Rojo, J.; et al. A multivalent inhibitor of the DC-SIGN dependent uptake of HIV-1 and Dengue virus. Biomaterials 2014, 35, 4175-4184. [CrossRef] 
96. Berzi, A.; Ordanini, S.; Joosten, B.; Trabattoni, D.; Cambi, A.; Bernardi, A.; Clerici, M. Pseudo-Mannosylated DC-SIGN Ligands as Immunomodulants. Sci. Rep. 2016, 6, 35373. [CrossRef]

97. Naarding, M.A.; Baan, E.; Pollakis, G.; Paxton, W.A. Effect of chloroquine on reducing HIV-1 replication in vitro and the DC-SIGN mediated transfer of virus to CD4+T-lymphocytes. Retrovirology 2007, 4, 6. [CrossRef]

98. Pustylnikov, S.; Dave, R.S.; Khan, Z.K.; Porkolab, V.; Rashad, A.A.; Hutchinson, M.; Fieschi, F.; Chaiken, I.; Jain, P. Short Communication: Inhibition of DC-SIGN-Mediated HIV-1 Infection by Complementary Actions of Dendritic Cell Receptor Antagonists and Env-Targeting Virus Inactivators. AIDS Res. Hum. Retrovir. 2016, 32, 93-100. [CrossRef]

99. Nair, M.P.; Reynolds, J.L.; Mahajan, S.D.; Schwartz, S.A.; Aalinkeel, R.; Bindukumar, B.; Sykes, D. RNAi-directed inhibition of DC-SIGN by dendritic cells: Prospects for HIV-1 therapy. Aaps. J. 2005, 7, E572-E578. [CrossRef]

100. Geyer, H.; Will, C.; Feldmann, H.; Klenk, H.D.; Geyer, R. Carbohydrate structure of Marburg virus glycoprotein. Glycobiology 1992, 2, 299-312. [CrossRef]

101. Simmons, G.; Reeves, J.D.; Grogan, C.C.; Vandenberghe, L.H.; Baribaud, F.; Whitbeck, J.C.; Burke, E.; Buchmeier, M.J.; Soilleux, E.J.; Riley, J.L.; et al. DC-SIGN and DC-SIGNR bind ebola glycoproteins and enhance infection of macrophages and endothelial cells. Virology 2003, 305, 115-123. [CrossRef]

102. Francica, J.R.; Varela-Rohena, A.; Medvec, A.; Plesa, G.; Riley, J.L.; Bates, P. Steric shielding of surface epitopes and impaired immune recognition induced by the ebola virus glycoprotein. PLoS Pathog. 2010, 6, e1001098. [CrossRef]

103. Lennemann, N.J.; Rhein, B.A.; Ndungo, E.; Chandran, K.; Qiu, X.; Maury, W. Comprehensive functional analysis of N-linked glycans on Ebola virus GP1. mBio 2014, 5, e00862-13. [CrossRef]

104. Marzi, A.; Möller, P.; Hanna, S.L.; Harrer, T.; Eisemann, J.; Steinkasserer, A.; Becker, S.; Baribaud, F.; Pöhlmann, S. Analysis of the interaction of Ebola virus glycoprotein with DC-SIGN (dendritic cell-specific intercellular adhesion molecule 3-grabbing nonintegrin) and its homologue DC-SIGNR. J. Infect. Dis. 2007, 196 (Suppl. 2), S237-S246. [CrossRef]

105. Lasala, F.; Arce, E.; Otero, J.R.; Rojo, J.; Delgado, R. Mannosyl glycodendritic structure inhibits DC-SIGN-mediated Ebola virus infection in cis and in trans. Antimicrob. Agents Chemother 2003, 47, 3970-3972. [CrossRef]

106. Ribeiro-Viana, R.; Sánchez-Navarro, M.; Luczkowiak, J.; Koeppe, J.R.; Delgado, R.; Rojo, J.; Davis, B.G. Virus-like glycodendrinanoparticles displaying quasi-equivalent nested polyvalency upon glycoprotein platforms potently block viral infection. Nat. Commun. 2012, 3, 1303. [CrossRef]

107. Thépaut, M.; Luczkowiak, J.; Vivès, C.; Labiod, N.; Bally, I.; Lasala, F.; Grimoire, Y.; Fenel, D.; Sattin, S.; Thielens, N.; et al. DC/L-SIGN recognition of spike glycoprotein promotes SARS-CoV-2 trans-infection and can be inhibited by a glycomimetic antagonist. bioRxiv 2020. [CrossRef]

108. Cummings, R.D.; McEver, R.P. C-type Lectins. In Essentials of Glycobiology; Harbor Laboratory (NY): New York, NY, USA, 2009.

109. Kansas, G.S. Selectins and their ligands: Current concepts and controversies. Blood 1996, 88, 3259-3287. [CrossRef]

110. Vestweber, D.; Blanks, J.E. Mechanisms that regulate the function of the selectins and their ligands. Physiol. Rev. 1999, 79, 181-213. [CrossRef]

111. Foxall, C.; Watson, S.R.; Dowbenko, D.; Fennie, C.; Lasky, L.A.; Kiso, M.; Hasegawa, A.; Asa, D.; Brandley, B.K. The three members of the selectin receptor family recognize a common carbohydrate epitope, the sialyl Lewis(x) oligosaccharide. J. Cell Biol. 1992, 117, 895-902. [CrossRef]

112. Trinchera, M.; Aronica, A.; Dall'Olio, F. Selectin Ligands Sialyl-Lewis a and Sialyl-Lewis x in Gastrointestinal Cancers. Biology 2017, 6, 16. [CrossRef]

113. Somers, W.S.; Tang, J.; Shaw, G.D.; Camphausen, R.T. Insights into the molecular basis of leukocyte tethering and rolling revealed by structures of P- and E-selectin bound to SLe(X) and PSGL-1. Cell 2000, 103, 467-479. [CrossRef]

114. Eppihimer, M.J.; Wolitzky, B.; Anderson, D.C.; Labow, M.A.; Granger, D.N. Heterogeneity of expression of E- and P-selectins in vivo. Circ. Res. 1996, 79, 560-569. [CrossRef]

115. Ivetic, A.; Hoskins Green, H.L.; Hart, S.J. L-selectin: A Major Regulator of Leukocyte Adhesion, Migration and Signaling. Front. Immunol. 2019, 10, 1068. [CrossRef]

116. Peschon, J.J.; Slack, J.L.; Reddy, P.; Stocking, K.L.; Sunnarborg, S.W.; Lee, D.C.; Russell, W.E.; Castner, B.J.; Johnson, R.S.; Fitzner, J.N.; et al. An essential role for ectodomain shedding in mammalian development. Science 1998, 282, 1281-1284. [CrossRef]

117. McEver, R.P. Selectin-carbohydrate interactions during inflammation and metastasis. Glycoconj. J. 1997, 14, 585-591. [CrossRef]

118. Bullard, D.C.; Kunkel, E.J.; Kubo, H.; Hicks, M.J.; Lorenzo, I.; Doyle, N.A.; Doerschuk, C.M.; Ley, K.; Beaudet, A.L. Infectious susceptibility and severe deficiency of leukocyte rolling and recruitment in E-selectin and P-selectin double mutant mice. J. Exp. Med. 1996, 183, 2329-2336. [CrossRef]

119. Chen, S.; Alon, R.; Fuhlbrigge, R.C.; Springer, T.A. Rolling and transient tethering of leukocytes on antibodies reveal specializations of selectins. Proc. Natl. Acad. Sci. USA 1997, 94, 3172-3177. [CrossRef] [PubMed]

120. Mayadas, T.N.; Johnson, R.C.; Rayburn, H.; Hynes, R.O.; Wagner, D.D. Leukocyte rolling and extravasation are severely compromised in P selectin-deficient mice. Cell 1993, 74, 541-554. [CrossRef]

121. Luscinskas, F.W.; Kansas, G.S.; Ding, H.; Pizcueta, P.; Schleiffenbaum, B.E.; Tedder, T.F.; Gimbrone, M.A., Jr. Monocyte rolling, arrest and spreading on IL-4-activated vascular endothelium under flow is mediated via sequential action of L-selectin, beta 1-integrins, and beta 2-integrins. J. Cell Biol. 1994, 125, 1417-1427. [CrossRef]

122. Bargatze, R.F.; Kurk, S.; Butcher, E.C.; Jutila, M.A. Neutrophils roll on adherent neutrophils bound to cytokine-induced endothelial cells via L-selectin on the rolling cells. J. Exp. Med. 1994, 180, 1785-1792. [CrossRef] 
123. Wang, H.B.; Wang, J.T.; Zhang, L.; Geng, Z.H.; Xu, W.L.; Xu, T.; Huo, Y.; Zhu, X.; Plow, E.F.; Chen, M.; et al. P-selectin primes leukocyte integrin activation during inflammation. Nat. Immunol. 2007, 8, 882-892. [CrossRef] [PubMed]

124. Zarbock, A.; Abram, C.L.; Hundt, M.; Altman, A.; Lowell, C.A.; Ley, K. PSGL-1 engagement by E-selectin signals through Src kinase Fgr and ITAM adapters DAP12 and FcR gamma to induce slow leukocyte rolling. J. Exp. Med. 2008, 205, 2339-2347. [CrossRef] [PubMed]

125. Weyrich, A.S.; McIntyre, T.M.; McEver, R.P.; Prescott, S.M.; Zimmerman, G.A. Monocyte tethering by P-selectin regulates monocyte chemotactic protein-1 and tumor necrosis factor-alpha secretion. Signal integration and NF-kappa B translocation. J. Clin. Investig. 1995, 95, 2297-2303. [CrossRef]

126. Crockett-Torabi, E.; Sulenbarger, B.; Smith, C.W.; Fantone, J.C. Activation of human neutrophils through L-selectin and Mac-1 molecules. J. Immunol. 1995, 154, 2291-2302.

127. Palabrica, T.; Lobb, R.; Furie, B.C.; Aronovitz, M.; Benjamin, C.; Hsu, Y.M.; Sajer, S.A.; Furie, B. Leukocyte accumulation promoting fibrin deposition is mediated in vivo by P-selectin on adherent platelets. Nature 1992, 359, 848-851. [CrossRef]

128. Polgar, J.; Matuskova, J.; Wagner, D.D. The P-selectin, tissue factor, coagulation triad. J. Thromb. Haemost. 2005, 3, 1590-1596. [CrossRef]

129. Subramaniam, M.; Frenette, P.S.; Saffaripour, S.; Johnson, R.C.; Hynes, R.O.; Wagner, D.D. Defects in hemostasis in P-selectindeficient mice. Blood 1996, 87, 1238-1242. [CrossRef] [PubMed]

130. Arbonés, M.L.; Ord, D.C.; Ley, K.; Ratech, H.; Maynard-Curry, C.; Otten, G.; Capon, D.J.; Tedder, T.F. Lymphocyte homing and leukocyte rolling and migration are impaired in L-selectin-deficient mice. Immunity 1994, 1, 247-260. [CrossRef]

131. Läubli, H.; Borsig, L. Selectins as mediators of lung metastasis. Cancer Microenviron. Off. J. Int. Cancer Microenviron. Soc. 2010, 3 , 97-105. [CrossRef] [PubMed]

132. Khatib, A.M.; Kontogiannea, M.; Fallavollita, L.; Jamison, B.; Meterissian, S.; Brodt, P. Rapid induction of cytokine and E-selectin expression in the liver in response to metastatic tumor cells. Cancer Res. 1999, 59, 1356-1361. [PubMed]

133. Barbier, V.; Erbani, J.; Fiveash, C.; Davies, J.M.; Tay, J.; Tallack, M.R.; Lowe, J.; Magnani, J.L.; Pattabiraman, D.R.; Perkins, A.C.; et al. Endothelial E-selectin inhibition improves acute myeloid leukaemia therapy by disrupting vascular niche-mediated chemoresistance. Nat. Commun. 2020, 11, 2042. [CrossRef]

134. Muz, B.; Abdelghafer, A.; Markovic, M.; Yavner, J.; Melam, A.; Salama, N.N.; Azab, A.K. Targeting E-selectin to Tackle Cancer Using Uproleselan. Cancers 2021, 13, 335. [CrossRef] [PubMed]

135. Kageshita, T.; Hirai, S.; Kimura, T.; Hanai, N.; Ohta, S.; Ono, T. Association between sialyl Lewis(a) expression and tumor progression in melanoma. Cancer Res. 1995, 55, 1748-1751. [CrossRef]

136. Numahata, K.; Satoh, M.; Handa, K.; Saito, S.; Ohyama, C.; Ito, A.; Takahashi, T.; Hoshi, S.; Orikasa, S.; Hakomori, S.I. Sialosyl-Le(x) expression defines invasive and metastatic properties of bladder carcinoma. Cancer 2002, 94, 673-685. [CrossRef]

137. Villar-Portela, S.; Martin, C.; Muinelo-Romay, L.; Cuevas, E.; Gil Martín, E.; Fernández, A. sLe a and sLe x expression in colorectal cancer: Implications for tumourigenesis and disease prognosis. Histol. Histopathol. 2011, 26, 1305-1316. [CrossRef]

138. Zhong, L.; Simoneau, B.; Tremblay, P.-L.; Gout, S.; Simard, M.J.; Huot, J. E-Selectin-mediated adhesion and extravasation in cancer. Encycl. Cancer 2017, 1618-1624.

139. DeAngelo, D.J.; Jonas, B.A.; Liesveld, J.L.; Bixby, D.L.; Advani, A.S.; Marlton, P.; O’Dwyer, M.E.; Fogler, W.E.; Magnani, J.L.; Chen, M.M.; et al. High E-Selectin Ligand Expression Contributes to Chemotherapy-Resistance in Poor Risk Relapsed and Refractory (R/R) Acute Myeloid Leukemia Patients and Can be Overcome with the Addition of Uproleselan. Blood 2019, 134, 2690. [CrossRef]

140. Winkler, I.G.; Barbier, V.; Nowlan, B.; Jacobsen, R.N.; Forristal, C.E.; Patton, J.T.; Magnani, J.L.; Lévesque, J.P. Vascular niche E-selectin regulates hematopoietic stem cell dormancy, self renewal and chemoresistance. Nat. Med. 2012, 18, $1651-1657$. [CrossRef] [PubMed]

141. Esposito, M.; Mondal, N.; Greco, T.M.; Wei, Y.; Spadazzi, C.; Lin, S.C.; Zheng, H.; Cheung, C.; Magnani, J.L.; Lin, S.H.; et al. Bone vascular niche E-selectin induces mesenchymal-epithelial transition and Wnt activation in cancer cells to promote bone metastasis. Nat. Cell Biol. 2019, 21, 627-639. [CrossRef]

142. Chen, M.; Geng, J.G. P-selectin mediates adhesion of leukocytes, platelets, and cancer cells in inflammation, thrombosis, and cancer growth and metastasis. Arch. Immunol. Ther. Exp. 2006, 54, 75-84. [CrossRef] [PubMed]

143. Ernst, B.; Magnani, J.L. From carbohydrate leads to glycomimetic drugs. Nat. Reviews Drug Discov. 2009, 8, 661-677. [CrossRef] [PubMed]

144. Munkley, J.; Scott, E. Targeting Aberrant Sialylation to Treat Cancer. Medicines 2019, 6, 102. [CrossRef]

145. DeAngelo, D.J.; Jonas, B.A.; Liesveld, J.L.; Bixby, D.L.; Advani, A.S.; Marlton, P.; O’Dwyer, M.E.; Fogler, W.E.; Wolfgang, C.D.; Magnani, J.L.; et al. Uproleselan (GMI-1271), an E-Selectin Antagonist, Improves the Efficacy and Safety of Chemotherapy in Relapsed/Refractory (R/R) and Newly Diagnosed Older Patients with Acute Myeloid Leukemia: Final, Correlative, and Subgroup Analyses. Blood 2018, 132, 331. [CrossRef]

146. DeAngelo, D.J.; Erba, H.P.; Jonas, B.A.; O’Dwyer, M.; Marlton, P.; Huls, G.A.; Liesveld, J.; Cooper, B.W.; Bhatnagar, B.; Armstrong, M.; et al. A phase III trial to evaluate the efficacy of uproleselan (GMI-1271) with chemotherapy in patients with relapsed/refractory acute myeloid leukemia. J. Clin. Oncol. 2019, 37, TPS7066. [CrossRef] 
147. Muz, B.; Azab, F.; Fiala, M.; King, J.; Kohnen, D.; Fogler, W.E.; Smith, T.; Magnani, J.L.; Vij, R.; Azab, A.K. Inhibition of E-Selectin (GMI-1271) or E-selectin together with CXCR4 (GMI-1359) re-sensitizes multiple myeloma to therapy. Blood Cancer J. $2019,9,68$. [CrossRef]

148. Kononchik, J.; Ireland, J.; Zou, Z.; Segura, J.; Holzapfel, G.; Chastain, A.; Wang, R.; Spencer, M.; He, B.; Stutzman, N.; et al. HIV-1 targets L-selectin for adhesion and induces its shedding for viral release. Nat. Commun. 2018, 9, 2825. [CrossRef]

149. Giuliani, E.; Vassena, L.; Galardi, S.; Michienzi, A.; Desimio, M.G.; Doria, M. Dual regulation of L-selectin (CD62L) by HIV-1: Enhanced expression by Vpr in contrast with cell-surface down-modulation by Nef and Vpu. Virology 2018, 523, 121-128. [CrossRef]

150. Vassena, L.; Giuliani, E.; Koppensteiner, H.; Bolduan, S.; Schindler, M.; Doria, M. HIV-1 Nef and Vpu Interfere with L-Selectin (CD62L) Cell Surface Expression To Inhibit Adhesion and Signaling in Infected CD4+ T Lymphocytes. J. Virol. 2015, 89, 5687-5700. [CrossRef] [PubMed]

151. Mohammed, R.N.; Watson, H.A.; Vigar, M.; Ohme, J.; Thomson, A.; Humphreys, I.R.; Ager, A. L-selectin Is Essential for Delivery of Activated CD8(+) T Cells to Virus-Infected Organs for Protective Immunity. Cell Rep. 2016, 14, 760-771. [CrossRef] [PubMed]

152. Yang, S.; Liu, F.; Wang, Q.J.; Rosenberg, S.A.; Morgan, R.A. The shedding of CD62L (L-selectin) regulates the acquisition of lytic activity in human tumor reactive T lymphocytes. PLOS ONE 2011, 6, e22560. [CrossRef]

153. Hoffman, M.; Ipp, H.; Phatlhane, D.V.; Erasmus, R.T.; Zemlin, A.E. E-Selectin and markers of HIV disease severity, inflammation and coagulation in HIV-infected treatment-naïve individuals. Afr. Health Sci. 2018, 18, 1066-1075. [CrossRef] [PubMed]

154. Cota-Gomez, A.; Flores, N.C.; Cruz, C.; Casullo, A.; Aw, T.Y.; Ichikawa, H.; Schaack, J.; Scheinman, R.; Flores, S.C. The human immunodeficiency virus-1 Tat protein activates human umbilical vein endothelial cell E-selectin expression via an NF-kappa B-dependent mechanism. J. Biol. Chem. 2002, 277, 14390-14399. [CrossRef] [PubMed]

155. Colomb, F.; Giron, L.B.; Kuri-Cervantes, L.; Adeniji, O.S.; Ma, T.; Dweep, H.; Battivelli, E.; Verdin, E.; Palmer, C.S.; Tateno, H.; et al Sialyl-Lewis $(X)$ Glycoantigen Is Enriched on Cells with Persistent HIV Transcription during Therapy. Cell Rep. 2020, $32,107991$. [CrossRef]

156. Fu, Y.; He, S.; Waheed, A.A.; Dabbagh, D.; Zhou, Z.; Trinité, B.; Wang, Z.; Yu, J.; Wang, D.; Li, F.; et al. PSGL-1 restricts HIV-1 infectivity by blocking virus particle attachment to target cells. Proc. Natl. Acad. Sci. USA 2020, 117, 9537-9545. [CrossRef]

157. He, S.; Waheed, A.A.; Hetrick, B.; Dabbagh, D.; Akhrymuk, I.V.; Kehn-Hall, K.; Freed, E.O.; Wu, Y. PSGL-1 Inhibits the Incorporation of SARS-CoV and SARS-CoV-2 Spike Glycoproteins into Pseudovirions and Impairs Pseudovirus Attachment and Infectivity. Viruses 2021, 13, 46. [CrossRef]

158. Barondes, S.H.; Castronovo, V.; Cooper, D.N.; Cummings, R.D.; Drickamer, K.; Feizi, T.; Gitt, M.A.; Hirabayashi, J.; Hughes, C.; Kasai, K.; et al. Galectins: A family of animal beta-galactoside-binding lectins. Cell 1994, 76, 597-598. [CrossRef]

159. Varki, A.; Cummings, R.D.; Esko, J.D.; Freeze, H.H.; Stanley, P.; Bertozzi, C.R.; Hart, G.W.; Etzler, M.E. Essentials of Glycobiology, 2nd ed.; Cold Spring Harbor Laboratory Press: New York, NY, USA, 2009.

160. Cummings, R.D.; Liu, F.T.; Vasta, G.R. Galectins. In Essentials of Glycobiology, 3rd ed.; Cold Spring Harbor: New York, NY, USA, 2017.

161. Rabinovich, G.A.; Liu, F.T.; Hirashima, M.; Anderson, A. An emerging role for galectins in tuning the immune response: Lessons from experimental models of inflammatory disease, autoimmunity and cancer. Scand. J. Immunol. 2007, 66, 143-158. [CrossRef] [PubMed]

162. Hirabayashi, J.; Kasai, K. The family of metazoan metal-independent beta-galactoside-binding lectins: Structure, function and molecular evolution. Glycobiology 1993, 3, 297-304. [CrossRef] [PubMed]

163. Girotti, M.R.; Salatino, M.; Dalotto-Moreno, T.; Rabinovich, G.A. Sweetening the hallmarks of cancer: Galectins as multifunctional mediators of tumor progression. J. Exp. Med. 2020, 217, e20182041. [CrossRef] [PubMed]

164. Wang, W.H.; Lin, C.Y.; Chang, M.R.; Urbina, A.N.; Assavalapsakul, W.; Thitithanyanont, A.; Chen, Y.H.; Liu, F.T.; Wang, S.F. The role of galectins in virus infection-A systemic literature review. J. Microbiol. Immunol. Infect. 2020, 53, 925-935. [CrossRef] [PubMed]

165. Leffler, H.; Barondes, S.H. Specificity of binding of three soluble rat lung lectins to substituted and unsubstituted mammalian beta-galactosides. J. Biol. Chem. 1986, 261, 10119-10126. [CrossRef]

166. Zhou, Q.; Cummings, R.D. The S-type lectin from calf heart tissue binds selectively to the carbohydrate chains of laminin. Arch. Biochem. Biophys. 1990, 281, 27-35. [CrossRef]

167. Bourne, Y.; Bolgiano, B.; Liao, D.-I.; Strecker, G.; Cantau, P.; Herzberg, O.; Feizi, T.; Cambillau, C. Crosslinking of mammalian lectin (galectin-1) by complex biantennary saccharides. Nat. Struct. Biol. 1994, 1, 863-870. [CrossRef] [PubMed]

168. Brewer, C.F.; Miceli, M.C.; Baum, L.G. Clusters, bundles, arrays and lattices: Novel mechanisms for lectin-saccharide-mediated cellular interactions. Curr. Opin. Struct. Biol. 2002, 12, 616-623. [CrossRef]

169. Sharon, N. When lectin meets oligosaccharide. Nat. Struct. Biol. 1994, 1, 843-845. [CrossRef]

170. Ahmad, N.; Gabius, H.J.; Kaltner, H.; André, S.; Kuwabara, I.; Liu, F.-T.; Oscarson, S.; Norberg, T.; Brewer, C.F. Thermodynamic binding studies of cell surface carbohydrate epitopes to galectins-1, -3, and -7: Evidence for differential binding specificities. Can. J. Chem. 2002, 80, 1096-1104. [CrossRef]

171. Hirashima, M.; Kashio, Y.; Nishi, N.; Yamauchi, A.; Imaizumi, T.A.; Kageshita, T.; Saita, N.; Nakamura, T. Galectin-9 in physiological and pathological conditions. Glycoconj. J. 2002, 19, 593-600. [CrossRef] [PubMed] 
172. Ahmad, N.; Gabius, H.J.; André, S.; Kaltner, H.; Sabesan, S.; Roy, R.; Liu, B.; Macaluso, F.; Brewer, C.F. Galectin-3 precipitates as a pentamer with synthetic multivalent carbohydrates and forms heterogeneous cross-linked complexes. J. Biol. Chem. 2004, 279, 10841-10847. [CrossRef]

173. Ideo, H.; Seko, A.; Yamashita, K. Recognition mechanism of galectin-4 for cholesterol 3-sulfate. J. Biol. Chem. 2007, 282, 21081-21089. [CrossRef] [PubMed]

174. Fermin Lee, A.; Chen, H.Y.; Wan, L.; Wu, S.Y.; Yu, J.S.; Huang, A.C.; Miaw, S.C.; Hsu, D.K.; Wu-Hsieh, B.A.; Liu, F.T. Galectin-3 modulates Th17 responses by regulating dendritic cell cytokines. Am. J. Pathol. 2013, 183, 1209-1222. [CrossRef] [PubMed]

175. Rabinovich, G.A.; Iglesias, M.M.; Modesti, N.M.; Castagna, L.F.; Wolfenstein-Todel, C.; Riera, C.M.; Sotomayor, C.E. Activated rat macrophages produce a galectin-1-like protein that induces apoptosis of T cells: Biochemical and functional characterization. J. Immunol. 1998, 160, 4831-4840. [PubMed]

176. Frigeri, L.G.; Liu, F.T. Surface expression of functional IgE binding protein, an endogenous lectin, on mast cells and macrophages. J. Immunol. 1992, 148, 861-867.

177. Ge, X.N.; Ha, S.G.; Liu, F.-T.; Rao, S.P.; Sriramarao, P. Eosinophil-expressed galectin-3 regulates cell trafficking and migration. Front. Pharm. 2013, 4, 37. [CrossRef] [PubMed]

178. Lingblom, C.; Andersson, K.; Wennerås, C. Kinetic studies of galectin-10 release from eosinophils exposed to proliferating T cells. Clin. Exp. Immunol. 2021, 203, 230-243. [CrossRef] [PubMed]

179. Truong, M.J.; Gruart, V.; Kusnierz, J.P.; Papin, J.P.; Loiseau, S.; Capron, A.; Capron, M. Human neutrophils express immunoglobulin E (IgE)-binding proteins (Mac-2/epsilon BP) of the S-type lectin family: Role in IgE-dependent activation. J. Exp. Med. 1993, 177, 243-248. [CrossRef]

180. Koopman, L.A.; Kopcow, H.D.; Rybalov, B.; Boyson, J.E.; Orange, J.S.; Schatz, F.; Masch, R.; Lockwood, C.J.; Schachter, A.D.; Park, P.J.; et al. Human decidual natural killer cells are a unique NK cell subset with immunomodulatory potential. J. Exp. Med. 2003, 198, 1201-1212. [CrossRef]

181. Blaser, C.; Kaufmann, M.; Müller, C.; Zimmermann, C.; Wells, V.; Mallucci, L.; Pircher, H. Beta-galactoside-binding protein secreted by activated T cells inhibits antigen-induced proliferation of T cells. Eur. J. Immunol. 1998, 28, 2311-2319. [CrossRef]

182. Meissner, N.; Radke, J.; Hedges, J.F.; White, M.; Behnke, M.; Bertolino, S.; Abrahamsen, M.; Jutila, M.A. Serial Analysis of Gene Expression in Circulating $\gamma \delta \mathrm{T}$ Cell Subsets Defines Distinct Immunoregulatory Phenotypes and Unexpected Gene Expression Profiles. J. Immunol. 2003, 170, 356-364. [CrossRef] [PubMed]

183. Oliveira, F.L.; Chammas, R.; Ricon, L.; Fermino, M.L.; Bernardes, E.S.; Hsu, D.K.; Liu, F.-T.; Borojevic, R.; El-Cheikh, M.C. Galectin-3 regulates peritoneal B1-cell differentiation into plasma cells. Glycobiology 2009, 19, 1248-1258. [CrossRef] [PubMed]

184. Zuñiga, E.; Rabinovich, G.A.; Iglesias, M.M.; Gruppi, A. Regulated expression of galectin-1 during B-cell activation and implications for T-cell apoptosis. J. Leukoc. Biol. 2001, 70, 73-79.

185. Hernandez, J.D.; Baum, L.G. Ah, sweet mystery of death! Galectins and control of cell fate. Glycobiology 2002, 12, 127R-136R. [CrossRef] [PubMed]

186. Liu, F.T.; Patterson, R.J.; Wang, J.L. Intracellular functions of galectins. Biochim. Biophys. Acta 2002, 1572, 263-273. [CrossRef]

187. Elola, M.T.; Wolfenstein-Todel, C.; Troncoso, M.F.; Vasta, G.R.; Rabinovich, G.A. Galectins: Matricellular glycan-binding proteins linking cell adhesion, migration, and survival. Cell Mol. Life Sci. 2007, 64, 1679-1700. [CrossRef]

188. Garner, O.B.; Baum, L.G. Galectin-glycan lattices regulate cell-surface glycoprotein organization and signalling. Biochem. Soc. Trans. 2008, 36, 1472-1477. [CrossRef] [PubMed]

189. He, J.; Baum, L.G. Galectin interactions with extracellular matrix and effects on cellular function. Methods Enzym. 2006, 417, 247-256. [CrossRef]

190. Nabi, I.R.; Shankar, J.; Dennis, J.W. The galectin lattice at a glance. J. Cell Sci. 2015, 128, 2213-2219. [CrossRef] [PubMed]

191. Perillo, N.L.; Marcus, M.E.; Baum, L.G. Galectins: Versatile modulators of cell adhesion, cell proliferation, and cell death. J. Mol. Med. (Berl) 1998, 76, 402-412. [CrossRef] [PubMed]

192. Cooper, D.N.; Barondes, S.H. God must love galectins; he made so many of them. Glycobiology 1999, 9, 979-984. [CrossRef] [PubMed]

193. Liu, F.T.; Rabinovich, G.A. Galectins as modulators of tumour progression. Nat. Rev. Cancer 2005, 5, 29-41. [CrossRef]

194. Wdowiak, K.; Francuz, T.; Gallego-Colon, E.; Ruiz-Agamez, N.; Kubeczko, M.; Grochoła, I.; Wojnar, J. Galectin Targeted Therapy in Oncology: Current Knowledge and Perspectives. Int. J. Mol. Sci. 2018, 19, 210. [CrossRef]

195. Thijssen, V.L.; Heusschen, R.; Caers, J.; Griffioen, A.W. Galectin expression in cancer diagnosis and prognosis: A systematic review. Biochim. Biophys. Acta (BBA) Rev. Cancer 2015, 1855, 235-247. [CrossRef]

196. Hirabayashi, J.; Hashidate, T.; Arata, Y.; Nishi, N.; Nakamura, T.; Hirashima, M.; Urashima, T.; Oka, T.; Futai, M.; Muller, W.E.G.; et al. Oligosaccharide specificity of galectins: A search by frontal affinity chromatography. Biochim. Biophys. Acta (BBA) Gen. Subj. 2002, 1572, 232-254. [CrossRef]

197. Lau, K.S.; Partridge, E.A.; Grigorian, A.; Silvescu, C.I.; Reinhold, V.N.; Demetriou, M.; Dennis, J.W. Complex N-Glycan Number and Degree of Branching Cooperate to Regulate Cell Proliferation and Differentiation. Cell 2007, 129, 123-134. [CrossRef]

198. Stanley, P. A method to the madness of N-glycan complexity? Cell 2007, 129, 27-29. [CrossRef]

199. Camby, I.; Decaestecker, C.; Lefranc, F.; Kaltner, H.; Gabius, H.J.; Kiss, R. Galectin-1 knocking down in human U87 glioblastoma cells alters their gene expression pattern. Biochem. Biophys. Res. Commun. 2005, 335, 27-35. [CrossRef] [PubMed] 
200. Puchades, M.; Nilsson, C.L.; Emmett, M.R.; Aldape, K.D.; Ji, Y.; Lang, F.F.; Liu, T.J.; Conrad, C.A. Proteomic investigation of glioblastoma cell lines treated with wild-type p53 and cytotoxic chemotherapy demonstrates an association between galectin-1 and p53 expression. J. Proteome Res. 2007, 6, 869-875. [CrossRef] [PubMed]

201. Raimond, J.; Rouleux, F.; Monsigny, M.; Legrand, A. The second intron of the human galectin-3 gene has a strong promoter activity down-regulated by p53. FEBS Lett. 1995, 363, 165-169. [CrossRef]

202. Potikha, T.; Pappo, O.; Mizrahi, L.; Olam, D.; Maller, S.M.; Rabinovich, G.A.; Galun, E.; Goldenberg, D.S. Lack of galectin-1 exacerbates chronic hepatitis, liver fibrosis, and carcinogenesis in murine hepatocellular carcinoma model. FASEB J. 2019, 33, 7995-8007. [CrossRef] [PubMed]

203. Rutkowski, M.R.; Stephen, T.L.; Svoronos, N.; Allegrezza, M.J.; Tesone, A.J.; Perales-Puchalt, A.; Brencicova, E.; Escovar-Fadul, X.; Nguyen, J.M.; Cadungog, M.G.; et al. Microbially driven TLR5-dependent signaling governs distal malignant progression through tumor-promoting inflammation. Cancer Cell 2015, 27, 27-40. [CrossRef] [PubMed]

204. Carvalho, R.S.; Fernandes, V.C.; Nepomuceno, T.C.; Rodrigues, D.C.; Woods, N.T.; Suarez-Kurtz, G.; Chammas, R.; Monteiro, A.N.; Carvalho, M.A. Characterization of LGALS3 (galectin-3) as a player in DNA damage response. Cancer Biol. Ther. 2014, 15, 840-850. [CrossRef]

205. Gebert, J.; Kloor, M.; Lee, J.; Lohr, M.; André, S.; Wagner, R.; Kopitz, J.; Gabius, H.J. Colonic carcinogenesis along different genetic routes: Glycophenotyping of tumor cases separated by microsatellite instability/stability. Histochem. Cell Biol. 2012, 138, 339-350. [CrossRef]

206. Chen, C.; Duckworth, C.A.; Zhao, Q.; Pritchard, D.M.; Rhodes, J.M.; Yu, L.G. Increased circulation of galectin-3 in cancer induces secretion of metastasis-promoting cytokines from blood vascular endothelium. Clin. Cancer Res. 2013, 19, 1693-1704. [CrossRef]

207. Lee, Y.K.; Lin, T.H.; Chang, C.F.; Lo, Y.L. Galectin-3 silencing inhibits epirubicin-induced ATP binding cassette transporters and activates the mitochondrial apoptosis pathway via $\beta$-catenin/GSK-3 $\beta$ modulation in colorectal carcinoma. PLoS ONE 2013, 8, e82478. [CrossRef]

208. Chauhan, D.; Li, G.; Podar, K.; Hideshima, T.; Neri, P.; He, D.; Mitsiades, N.; Richardson, P.; Chang, Y.; Schindler, J.; et al. A novel carbohydrate-based therapeutic GCS-100 overcomes bortezomib resistance and enhances dexamethasone-induced apoptosis in multiple myeloma cells. Cancer Res. 2005, 65, 8350-8358. [CrossRef]

209. Fukumori, T.; Kanayama, H.O.; Raz, A. The role of galectin-3 in cancer drug resistance. Drug Resist. Updat. 2007, 10, 101-108. [CrossRef] [PubMed]

210. Blanchard, H.; Yu, X.; Collins, P.M.; Bum-Erdene, K. Galectin-3 inhibitors: A patent review (2008-present). Expert. Opin. Ther. Pat. 2014, 24, 1053-1065. [CrossRef]

211. Chou, F.C.; Chen, H.Y.; Kuo, C.C.; Sytwu, H.K. Role of Galectins in Tumors and in Clinical Immunotherapy. Int. J. Mol. Sci. 2018, 19, 430. [CrossRef]

212. Goud, N.S.; Soukya, P.S.L.; Ghouse, M.; Komal, D.; Alvala, R.; Alvala, M. Human Galectin-1 and Its Inhibitors: Privileged Target for Cancer and HIV. Mini. Rev. Med. Chem. 2019, 19, 1369-1378. [CrossRef]

213. Miller, M.C.; Klyosov, A.; Mayo, K.H. The alpha-galactomannan Davanat binds galectin-1 at a site different from the conventional galectin carbohydrate binding domain. Glycobiology 2009, 19, 1034-1045. [CrossRef]

214. Oberg, C.T.; Leffler, H.; Nilsson, U.J. Inhibition of galectins with small molecules. Chimia 2011, 65, 18-23. [CrossRef]

215. Klyosov, A.; Zomer, E.; Platt, D. DAVANAT ${ }^{\circledR}$ (GM-CT-01) and Colon Cancer: Preclinical and Clinical (Phase I and II) Studies. In Glycobiology and Drug Design; ACS Symposium Series; American Chemical Society: Washington, DC, USA, 2012; Volume 1102, pp. 89-130.

216. Cada, Z.; Smetana, K., Jr.; Lacina, L.; Plzáková, Z.; Stork, J.; Kaltner, H.; Russwurm, R.; Lensch, M.; André, S.; Gabius, H.J. Immunohistochemical fingerprinting of the network of seven adhesion/growth-regulatory lectins in human skin and detection of distinct tumour-associated alterations. Folia. Biol. 2009, 55, 145-152.

217. Kageshita, T.; Kashio, Y.; Yamauchi, A.; Seki, M.; Abedin, M.J.; Nishi, N.; Shoji, H.; Nakamura, T.; Ono, T.; Hirashima, M. Possible role of galectin-9 in cell aggregation and apoptosis of human melanoma cell lines and its clinical significance. Int. J. Cancer 2002, 99, 809-816. [CrossRef]

218. Kasamatsu, A.; Uzawa, K.; Nakashima, D.; Koike, H.; Shiiba, M.; Bukawa, H.; Yokoe, H.; Tanzawa, H. Galectin-9 as a regulator of cellular adhesion in human oral squamous cell carcinoma cell lines. Int. J. Mol. Med. 2005, 16, 269-273. [CrossRef] [PubMed]

219. Liang, M.; Ueno, M.; Oomizu, S.; Arikawa, T.; Shinonaga, R.; Zhang, S.; Yamauchi, A.; Hirashima, M. Galectin-9 expression links to malignant potential of cervical squamous cell carcinoma. J. Cancer Res. Clin. Oncol. 2008, 134, 899-907. [CrossRef]

220. Zhang, Z.Y.; Dong, J.H.; Chen, Y.W.; Wang, X.Q.; Li, C.H.; Wang, J.; Wang, G.Q.; Li, H.L.; Wang, X.D. Galectin-9 acts as a prognostic factor with antimetastatic potential in hepatocellular carcinoma. Asian Pac. J. Cancer Prev. 2012, 13, 2503-2509. [CrossRef]

221. Chan, S.W.; Kallarakkal, T.G.; Abraham, M.T. Changed expression of E-cadherin and galectin-9 in oral squamous cell carcinomas but lack of potential as prognostic markers. Asian Pac. J. Cancer Prev. 2014, 15, 2145-2152. [CrossRef]

222. Terris, B.; Blaveri, E.; Crnogorac-Jurcevic, T.; Jones, M.; Missiaglia, E.; Ruszniewski, P.; Sauvanet, A.; Lemoine, N.R. Characterization of gene expression profiles in intraductal papillary-mucinous tumors of the pancreas. Am. J. Pathol. 2002, 160, $1745-1754$. [CrossRef]

223. Türeci, Ö.; Schmitt, H.; Fadle, N.; Pfreundschuh, M.; Sahin, U. Molecular Definition of a Novel Human Galectin Which Is Immunogenic in Patients with Hodgkin's Disease *. J. Biol. Chem. 1997, 272, 6416-6422. [CrossRef] 
224. Zhang, C.-X.; Huang, D.-J.; Baloche, V.; Zhang, L.; Xu, J.-X.; Li, B.-W.; Zhao, X.-R.; He, J.; Mai, H.-Q.; Chen, Q.-Y.; et al. Galectin-9 promotes a suppressive microenvironment in human cancer by enhancing STING degradation. Oncogenesis 2020, 9, 65. [CrossRef]

225. Gleason, M.K.; Lenvik, T.R.; McCullar, V.; Felices, M.; O’Brien, M.S.; Cooley, S.A.; Verneris, M.R.; Cichocki, F.; Holman, C.J.; Panoskaltsis-Mortari, A.; et al. Tim-3 is an inducible human natural killer cell receptor that enhances interferon gamma production in response to galectin-9. Blood 2012, 119, 3064-3072. [CrossRef]

226. Klibi, J.; Niki, T.; Riedel, A.; Pioche-Durieu, C.; Souquere, S.; Rubinstein, E.; Le Moulec, S.; Guigay, J.; Hirashima, M.; Guemira, F.; et al. Blood diffusion and Th1-suppressive effects of galectin-9-containing exosomes released by Epstein-Barr virus-infected nasopharyngeal carcinoma cells. Blood 2009, 113, 1957-1966. [CrossRef]

227. Li, H.; Wu, K.; Tao, K.; Chen, L.; Zheng, Q.; Lu, X.; Liu, J.; Shi, L.; Liu, C.; Wang, G.; et al. Tim-3/galectin-9 signaling pathway mediates T-cell dysfunction and predicts poor prognosis in patients with hepatitis B virus-associated hepatocellular carcinoma. Hepatology 2012, 56, 1342-1351. [CrossRef] [PubMed]

228. Monney, L.; Sabatos, C.A.; Gaglia, J.L.; Ryu, A.; Waldner, H.; Chernova, T.; Manning, S.; Greenfield, E.A.; Coyle, A.J.; Sobel, R.A.; et al. Th1-specific cell surface protein Tim-3 regulates macrophage activation and severity of an autoimmune disease. Nature 2002, 415, 536-541. [CrossRef] [PubMed]

229. Zhu, C.; Anderson, A.C.; Schubart, A.; Xiong, H.; Imitola, J.; Khoury, S.J.; Zheng, X.X.; Strom, T.B.; Kuchroo, V.K. The Tim-3 ligand galectin-9 negatively regulates T helper type 1 immunity. Nat. Immunol. 2005, 6, 1245-1252. [CrossRef]

230. John, S.; Mishra, R. Galectin-9: From cell biology to complex disease dynamics. J. Biosci. 2016, 41, 507-534. [CrossRef]

231. Gonçalves Silva, I.; Yasinska, I.M.; Sakhnevych, S.S.; Fiedler, W.; Wellbrock, J.; Bardelli, M.; Varani, L.; Hussain, R.; Siligardi, G.; Ceccone, G.; et al. The Tim-3-galectin-9 Secretory Pathway is Involved in the Immune Escape of Human Acute Myeloid Leukemia Cells. EBioMedicine 2017, 22, 44-57. [CrossRef]

232. Irie, A.; Yamauchi, A.; Kontani, K.; Kihara, M.; Liu, D.; Shirato, Y.; Seki, M.; Nishi, N.; Nakamura, T.; Yokomise, H.; et al. Galectin-9 as a prognostic factor with antimetastatic potential in breast cancer. Clin. Cancer Res. 2005, 11, 2962-2968. [CrossRef] [PubMed]

233. Akashi, E.; Fujihara, S.; Morishita, A.; Tadokoro, T.; Chiyo, T.; Fujikawa, K.; Kobara, H.; Mori, H.; Iwama, H.; Okano, K.; et al. Effects of galectin-9 on apoptosis, cell cycle and autophagy in human esophageal adenocarcinoma cells. Oncol. Rep. 2017, 38, 506-514. [CrossRef] [PubMed]

234. Chiyo, T.; Fujita, K.; Iwama, H.; Fujihara, S.; Tadokoro, T.; Ohura, K.; Matsui, T.; Goda, Y.; Kobayashi, N.; Nishiyama, N.; et al. Galectin-9 Induces Mitochondria-Mediated Apoptosis of Esophageal Cancer In Vitro and In Vivo in a Xenograft Mouse Model. Int. J. Mol. Sci. 2019, 20, 2634. [CrossRef] [PubMed]

235. Fujita, K.; Iwama, H.; Sakamoto, T.; Okura, R.; Kobayashi, K.; Takano, J.; Katsura, A.; Tatsuta, M.; Maeda, E.; Mimura, S.; et al. Galectin-9 suppresses the growth of hepatocellular carcinoma via apoptosis in vitro and in vivo. Int. J. Oncol. 2015, 46, 2419-2430. [CrossRef]

236. Itoh, A.; Nonaka, Y.; Ogawa, T.; Nakamura, T.; Nishi, N. Galectin-9 induces atypical ubiquitination leading to cell death in PC-3 prostate cancer cells. Glycobiology 2019, 29, 22-35. [CrossRef] [PubMed]

237. Jafari, S.M.; Nazri, A.; Shabani, M.; Balajam, N.Z.; Aghaei, M. Galectin-9 induces apoptosis in OVCAR-3 ovarian cancer cell through mitochondrial pathway. Res. Pharm. Sci. 2018, 13, 557-565. [CrossRef]

238. Kobayashi, K.; Morishita, A.; Iwama, H.; Fujita, K.; Okura, R.; Fujihara, S.; Yamashita, T.; Fujimori, T.; Kato, K.; Kamada, H.; et al. Galectin-9 suppresses cholangiocarcinoma cell proliferation by inducing apoptosis but not cell cycle arrest. Oncol. Rep. 2015, 34, 1761-1770. [CrossRef]

239. Kuroda, J.; Yamamoto, M.; Nagoshi, H.; Kobayashi, T.; Sasaki, N.; Shimura, Y.; Horiike, S.; Kimura, S.; Yamauchi, A.; Hirashima, M.; et al. Targeting Activating Transcription Factor 3 by Galectin-9 Induces Apoptosis and Overcomes Various Types of Treatment Resistance in Chronic Myelogenous Leukemia. Mol. Cancer Res. 2010, 8, 994-1001. [CrossRef]

240. Tadokoro, T.; Morishita, A.; Fujihara, S.; Iwama, H.; Niki, T.; Fujita, K.; Akashi, E.; Mimura, S.; Oura, K.; Sakamoto, T.; et al. Galectin-9: An anticancer molecule for gallbladder carcinoma. Int. J. Oncol. 2016, 48, 1165-1174. [CrossRef]

241. Takano, J.; Morishita, A.; Fujihara, S.; Iwama, H.; Kokado, F.; Fujikawa, K.; Fujita, K.; Chiyo, T.; Tadokoro, T.; Sakamoto, T.; et al. Galectin-9 suppresses the proliferation of gastric cancer cells in vitro. Oncol. Rep. 2016, 35, 851-860. [CrossRef]

242. Wiersma, V.R.; de Bruyn, M.; van Ginkel, R.J.; Sigar, E.; Hirashima, M.; Niki, T.; Nishi, N.; Samplonius, D.F.; Helfrich, W.; Bremer, E. The glycan-binding protein galectin-9 has direct apoptotic activity toward melanoma cells. J. Investig. Dermatol. 2012, 132, 2302-2305. [CrossRef]

243. Yang, R.; Sun, L.; Li, C.F.; Wang, Y.H.; Yao, J.; Li, H.; Yan, M.; Chang, W.C.; Hsu, J.M.; Cha, J.H.; et al. Galectin-9 interacts with PD-1 and TIM-3 to regulate T cell death and is a target for cancer immunotherapy. Nat. Commun. 2021, 12, 832. [CrossRef] [PubMed]

244. Baum, L.G.; Pang, M.; Perillo, N.L.; Wu, T.; Delegeane, A.; Uittenbogaart, C.H.; Fukuda, M.; Seilhamer, J.J. Human thymic epithelial cells express an endogenous lectin, galectin-1, which binds to core 2 O-glycans on thymocytes and Tymphoblastoid cells. J. Exp. Med. 1995, 181, 877-887. [CrossRef]

245. Perillo, N.L.; Uittenbogaart, C.H.; Nguyen, J.T.; Baum, L.G. Galectin-1, an endogenous lectin produced by thymic epithelial cells, induces apoptosis of human thymocytes. J. Exp. Med. 1997, 185, 1851-1858. [CrossRef] [PubMed]

246. Ouellet, M.; Mercier, S.; Pelletier, I.; Bounou, S.; Roy, J.; Hirabayashi, J.; Sato, S.; Tremblay, M.J. Galectin-1 Acts as a Soluble Host Factor That Promotes HIV-1 Infectivity through Stabilization of Virus Attachment to Host Cells. J. Immunol. 2005, 174, 4120-4126. [CrossRef] [PubMed] 
247. Mercier, S.; St-Pierre, C.; Pelletier, I.; Ouellet, M.; Tremblay, M.J.; Sato, S. Galectin-1 promotes HIV-1 infectivity in macrophages through stabilization of viral adsorption. Virology 2008, 371, 121-129. [CrossRef]

248. Lantéri, M.; Giordanengo, V.; Hiraoka, N.; Fuzibet, J.G.; Auberger, P.; Fukuda, M.; Baum, L.G.; Lefebvre, J.C. Altered T cell surface glycosylation in HIV-1 infection results in increased susceptibility to galectin-1-induced cell death. Glycobiology 2003, 13, 909-918. [CrossRef]

249. St-Pierre, C.; Ouellet, M.; Giguère, D.; Ohtake, R.; Roy, R.; Sato, S.; Tremblay, M.J. Galectin-1-specific inhibitors as a new class of compounds to treat HIV-1 infection. Antimicrob. Agents Chemother. 2012, 56, 154-162. [CrossRef]

250. Yang, M.L.; Chen, Y.H.; Wang, S.W.; Huang, Y.J.; Leu, C.H.; Yeh, N.C.; Chu, C.Y.; Lin, C.C.; Shieh, G.S.; Chen, Y.L.; et al. Galectin-1 binds to influenza virus and ameliorates influenza virus pathogenesis. J. Virol. 2011, 85, 10010-10020. [CrossRef] [PubMed]

251. Fogel, S.; Guittaut, M.; Legrand, A.; Monsigny, M.; Hébert, E. The Tat protein of HIV-1 induces galectin-3 expression. Glycobiology 1999, 9, 383-387. [CrossRef]

252. Jones, K.A. Tat and the HIV-1 promoter. Curr. Opin. Cell Biol. 1993, 5, 461-468. [CrossRef]

253. Wang, S.F.; Tsao, C.H.; Lin, Y.T.; Hsu, D.K.; Chiang, M.L.; Lo, C.H.; Chien, F.C.; Chen, P.; Arthur Chen, Y.M.; Chen, H.Y.; et al. Galectin-3 promotes HIV-1 budding via association with Alix and Gag p6. Glycobiology 2014, 24, 1022-1035. [CrossRef]

254. Xue, J.; Fu, C.; Cong, Z.; Peng, L.; Peng, Z.; Chen, T.; Wang, W.; Jiang, H.; Wei, Q.; Qin, C. Galectin-3 promotes caspase-independent cell death of HIV-1-infected macrophages. FEBS J. 2017, 284, 97-113. [CrossRef]

255. Barnard, D.L.; Huffman, J.H.; Morris, J.L.; Wood, S.G.; Hughes, B.G.; Sidwell, R.W. Evaluation of the antiviral activity of anthraquinones, anthrones and anthraquinone derivatives against human cytomegalovirus. Antiviral. Res. 1992, $17,63-77$. [CrossRef]

256. Lin, C.-W.; Wu, C.-F.; Hsiao, N.-W.; Chang, C.-Y.; Li, S.-W.; Wan, L.; Lin, Y.-J.; Lin, W.-Y. Aloe-emodin is an interferon-inducing agent with antiviral activity against Japanese encephalitis virus and enterovirus 71. Int. J. Antimicrob. Agents 2008, 32, 355-359. [CrossRef] [PubMed]

257. Shuangsuo, D.; Zhengguo, Z.; Yunru, C.; Xin, Z.; Baofeng, W.; Lichao, Y.; Yan'an, C. Inhibition of the replication of hepatitis B virus in vitro by emodin. Med. Sci. Monit. 2006, 12, Br302-Br306.

258. Sydiskis, R.J.; Owen, D.G.; Lohr, J.L.; Rosler, K.H.; Blomster, R.N. Inactivation of enveloped viruses by anthraquinones extracted from plants. Antimicrob. Agents Chemother. 1991, 35, 2463-2466. [CrossRef]

259. Li, S.W.; Yang, T.C.; Lai, C.C.; Huang, S.H.; Liao, J.M.; Wan, L.; Lin, Y.J.; Lin, C.W. Antiviral activity of aloe-emodin against influenza A virus via galectin-3 up-regulation. Eur. J. Pharmacol. 2014, 738, 125-132. [CrossRef]

260. Li, F. Receptor recognition mechanisms of coronaviruses: A decade of structural studies. J. Virol. 2015, 89, 1954-1964. [CrossRef] [PubMed]

261. Li, F. Structure, Function, and Evolution of Coronavirus Spike Proteins. Annu. Rev. Virol. 2016, 3, 237-261. [CrossRef] [PubMed]

262. Caniglia, J.L.; Guda, M.R.; Asuthkar, S.; Tsung, A.J.; Velpula, K.K. A potential role for Galectin-3 inhibitors in the treatment of COVID-19. PeerJ 2020, 8, e9392. [CrossRef] [PubMed]

263. Chen, S.S.; Sun, L.W.; Brickner, H.; Sun, P.Q. Downregulating galectin-3 inhibits proinflammatory cytokine production by human monocyte-derived dendritic cells via RNA interference. Cell Immunol. 2015, 294, 44-53. [CrossRef] [PubMed]

264. Ren, Z.; Liang, W.; Sheng, J.; Xun, C.; Xu, T.; Cao, R.; Sheng, W. Gal-3 is a potential biomarker for spinal cord injury and Gal-3 deficiency attenuates neuroinflammation through ROS/TXNIP/NLRP3 signaling pathway. Biosci. Rep. 2019, 39, BSR20192368. [CrossRef]

265. Sethi, A.; Sanam, S.; Munagalasetty, S.; Jayanthi, S.; Alvala, M. Understanding the role of galectin inhibitors as potential candidates for SARS-CoV-2 spike protein: In silico studies. RSC Advances 2020, 10, 29873-29884. [CrossRef]

266. Bi, S.; Hong, P.W.; Lee, B.; Baum, L.G. Galectin-9 binding to cell surface protein disulfide isomerase regulates the redox environment to enhance T-cell migration and HIV entry. Proc. Natl. Acad. Sci. USA 2011, 108, 10650-10655. [CrossRef]

267. Colomb, F.; Giron, L.B.; Premeaux, T.A.; Mitchell, B.I.; Niki, T.; Papasavvas, E.; Montaner, L.J.; Ndhlovu, L.C.; Abdel-Mohsen, M. Galectin-9 Mediates HIV Transcription by Inducing TCR-Dependent ERK Signaling. Front. Immunol. 2019, 10, 267. [CrossRef]

268. Jost, S.; Moreno-Nieves, U.Y.; Garcia-Beltran, W.F.; Rands, K.; Reardon, J.; Toth, I.; Piechocka-Trocha, A.; Altfeld, M.; Addo, M.M. Dysregulated Tim-3 expression on natural killer cells is associated with increased Galectin-9 levels in HIV-1 infection. Retrovirology 2013, 10, 74. [CrossRef]

269. Elahi, S.; Niki, T.; Hirashima, M.; Horton, H. Galectin-9 binding to Tim-3 renders activated human CD4+ T cells less susceptible to HIV-1 infection. Blood 2012, 119, 4192-4204. [CrossRef]

270. Abdel-Mohsen, M.; Wang, C.; Strain, M.C.; Lada, S.M.; Deng, X.; Cockerham, L.R.; Pilcher, C.D.; Hecht, F.M.; Liegler, T.; Richman, D.D.; et al. Select host restriction factors are associated with HIV persistence during antiretroviral therapy. Aids 2015, 29, 411-420. [CrossRef] [PubMed]

271. Abdel-Mohsen, M.; Chavez, L.; Tandon, R.; Chew, G.M.; Deng, X.; Danesh, A.; Keating, S.; Lanteri, M.; Samuels, M.L.; Hoh, R.; et al. Human Galectin-9 Is a Potent Mediator of HIV Transcription and Reactivation. PLoS Pathog. 2016, 12, e1005677. [CrossRef]

272. Katoh, S.; Ikeda, M.; Shimizu, H.; Mouri, K.; Obase, Y.; Kobashi, Y.; Fukushima, K.; Hirashima, M.; Oka, M. Increased levels of plasma galectin-9 in patients with influenza virus infection. Tohoku J. Exp. Med. 2014, 232, 263-267. [CrossRef] [PubMed]

273. Sharma, S.; Sundararajan, A.; Suryawanshi, A.; Kumar, N.; Veiga-Parga, T.; Kuchroo, V.K.; Thomas, P.G.; Sangster, M.Y.; Rouse, B.T. T cell immunoglobulin and mucin protein-3 (Tim-3)/Galectin-9 interaction regulates influenza A virus-specific humoral and CD8 T-cell responses. Proc. Natl. Acad. Sci. USA 2011, 22, 108. [CrossRef] [PubMed] 